\title{
Planning the Future Oral Health Workforce: A Rapid Review of Supply, Demand and Need Models, Data Sources and Skill Mix Considerations
}

\author{
Madhan Balasubramanian ${ }^{1,2,3, *}$, Aliya Hasan ${ }^{3}$, Suruchi Ganbavale ${ }^{3,4}$, Anfal Alolayah ${ }^{3}$ and Jennifer Gallagher ${ }^{3}$ \\ 1 Faculty of Medicine and Health, The University of Sydney, Sydney 2006, Australia \\ 2 Australian Research Centre for Population Oral Health, Adelaide Dental School, The University of Adelaide, \\ Adelaide 5005, Australia \\ 3 Faculty of Dentistry, Oral \& Craniofacial Sciences, Kings College London, London SE5 9RS, UK; \\ aliya.hasan@kcl.ac.uk (A.H.); SURUCHI.Ganbavale5@myport.ac.uk (S.G.); anfal.alolayah@kcl.ac.uk (A.A.); \\ jenny.gallagher@kcl.ac.uk (J.G.) \\ 4 Dental Academy, William Beatty Building, Hampshire Terrace, University of Portsmouth, \\ Portsmouth PO1 2QG, UK \\ * Correspondence: madhan.balasubramanian@sydney.edu.au; Tel.: +61-410-993-893
}

\section{check for}

updates

Citation: Balasubramanian, M.; Hasan, A.; Ganbavale, S.; Alolayah, A.; Gallagher, J. Planning the Future Oral Health Workforce: A Rapid Review of Supply, Demand and Need Models, Data Sources and Skill Mix Considerations. Int. J. Environ. Res. Public Health 2021, 18, 2891. https:// doi.org/10.3390/ijerph18062891

Academic Editors: Paul

B. Tchounwou and Takaaki Tomofuji

Received: 19 January 2021

Accepted: 9 March 2021

Published: 12 March 2021

Publisher's Note: MDPI stays neutral with regard to jurisdictional claims in published maps and institutional affiliations.

Copyright: (c) 2021 by the authors. Licensee MDPI, Basel, Switzerland. This article is an open access article distributed under the terms and conditions of the Creative Commons Attribution (CC BY) license (https:/ / creativecommons.org/licenses/by/ $4.0 /)$.

\begin{abstract}
Over the last decade, there has been a renewed interest in oral health workforce planning The purpose of this review is to examine oral health workforce planning models on supply, demand and needs, mainly in respect to their data sources, modelling technique and use of skill mix. A limited search was carried out on PubMed and Web of Science for published scientific articles on oral health workforce planning models between 2010 to 2020. No restrictions were placed on the type of modelling philosophy, and all studies including supply, demand or needs based models were included. Rapid review methods guided the review process. Twenty-three studies from 15 countries were included in the review. A majority were from high-income countries $(n=17)$. Dentists were the sole oral health workforce group modelled in 13 studies; only five studies included skill mix (allied dental personnel) considerations. The most common application of modelling was a workforce to population ratio or a needs-based demand weighted variant. Nearly all studies presented weaknesses in modelling process due to the limitations in data sources and/or non-availability of the necessary data to inform oral health workforce planning. Skill mix considerations in planning models were also limited to horizontal integration within oral health professionals. Planning for the future oral health workforce is heavily reliant on quality data being available for supply, demand and needs models. Integrated methodologies that expand skill mix considerations and account for uncertainty are essential for future planning exercises.
\end{abstract}

Keywords: health workforce; operational models; planning; skill mix; integration

\section{Introduction}

The health workforce is the backbone of health systems, fundamental towards achieving universal health coverage (UHC) and meeting sustainable development goals (SDGs) [1-3]. Planning for the future health workforce is a complex process, requiring trade-offs across multiple health professional objectives in education, training and regulation, and numerous uncertainties due to transition health environments (demographic, epidemiologic and technology) [4]. In general health workforce planning aims to achieve a proper balance between supply and demand of health professionals [5]. The philosophy behind planning is to ensure the right number of health personnel, with the right training and skill sets are available at the right place and at the right time to meet population needs, but at an acceptable cost and quality [6]. The process is not just technical, but a political one [6]. Planning decisions on the number, type and distribution of health personnel depend and 
are influenced by a range of social, economic and professional values enshrined within underlying health systems.

Planning for the future oral health workforce presents its unique challenges. First, the profession of dentistry, in many countries, has remained historically 'distinct' from the medical, nursing and broader health professions [7]. Silos are visible in the education and practice of dental professionals, that also extend to policy and planning decisions [7-9]. Second, dentists are at the center of the dental profession, entrusted with the responsibility of providing leadership, and serving as the first point of contact for the majority of oral health conditions [7]. The allied dental workforce-dental hygienists, dental therapists, dual qualified hygienist/therapists, dental technicians, denturists, prosthetists and dental assistants-support the dentist in the provision of care. However, the acceptance of allied dental professionals vary country to country and potentially reflect on the use of skill mix in planning decisions [10]. Third, dental specialists are the gatekeepers of the profession, providing exceptional services to 'special' patients, and serving as a focal point for quality benchmarks, innovation and adoption of new procedures, clinical research and education of the dental team [11]. Atleast 10 distinct specialist dental professionals exist: orthodontists, oral and maxillofacial surgeons, prosthodontists, periodontists, endodontists, paediatric dentists, oral pathologists, oral medicine, special needs and dental public health specialists. Not all dental specialities gain equal importance in the planning exercise. A further challenge in oral health workforce planning is consideration for both horizontal (i.e., within profession skill mix) and vertical (i.e., skill mix outside the dental profession) integration in planning models.

Traditionally, four broad approaches to health workforce planning have been identified in the literature: needs-based, utilisation or demand-based, health workforce to population ratio, and target setting approach $[4,12]$. Each of these approaches includes atleast one or more of the basic building blocks in modelling: supply, demand and need [13]. Supply models estimate the number of health personnel available based on the current stocks, flows/migration, and newly trained personnel. Demand or needs model estimate health personnel required to meet the underlying population demand or needs respectively. Needs are identified through epidemiological surveys, accounting for diseases prevalence and health status. Demand is identified through health service utilisation. Supply and demand/needs models are usually presented together, so the combined model can determine the gap in health personnel availability. Planning models are also classified as being deterministic or stochastic [12]. Deterministic models assume the outcome is certain, and always deliver the same results for the same input values. On the other hand, stochastic models allow for the introduction of random changes and provide means for building an element of uncertainty in the overall planning models.

Over the last decade, there has been a renewed interest in oral health workforce planning [14-16]. The purpose of this review is to examine oral health workforce planning models on supply, demand and needs, mainly in respect to their data sources, modelling technique and use of skill mix. We also identify strengths and weaknesses in these workforce models and provide insights on how oral health workforce planning can evolve in the future to meet changing population needs and demands, improving health outcomes and health systems performance.

\section{Methods}

The study was based on a rapid review approach adapted from Khangura et al. [17] and Thomas et al. [18]. Rapid reviews are a type of systematic reviews, where components of a regular systematic review are simplified or made more efficient to produce information in a shorter span of time, but with minimal impact to quality [19]. In recent years, rapid reviews have emerged as an efficient solution to synthesizing evidence to support health policymaking and health systems strengthening by providing high-quality evidence in a timely and cost-effective manner [20]. Our rapid review involved the following steps: (i) defining a review/research question (ii) developing a search strategy (iii) establishing 
selection/eligibility criteria (iv) screening and study selection (v) data extraction and (vi) synthesis of findings. We have adhered to Khangura et al.'s descriptive synthesis of findings and emphasis on translation of findings to policy and practice $[18,19]$. Targeted searching of key databases, and data abstraction by mapping study characteristics were adopted from Thomas et al. [17,19]. While no generic trend or adherence to any particular variant of rapid reviews have been observed in recent reviews $[19,21]$, our methodological underpinning to key schools of rapid review thought streamlines our approach and philosophy.

\subsection{Research Question}

The following question was formulated for this part of the review: What are the main operational models, data sources and techniques used in oral health workforce planning?

\subsection{Search Strategy}

A comprehensive search strategy was designed in consultation with an expert librarian at Kings College London to capture the relevant literature on the topic of interest. We included four broad categories in our search criteria: healthcare and workforce planning, dental service provision, dental staffing, modelling techniques and skill mix. Specific MeSH terms and keywords, along with Boolean operators were used to build the search. This list was refined by conducting a group discussion among all authors to arrive at a consensus. Electronic searches were carried out in 2 different databases: PubMed and Web of Science. The search strategy was designed for PubMed interface, and later revised for Web of Science. A limited literature search was undertaken for relevant titles, abstracts and keywords (please see Supplementary Tables S1 and S4). Standard techniques such as using truncation methods and searching for relevant references from the bibliography provided in searched papers and were also used. Manual forward-backward search or citation tracking of the identified articles were performed using Scopus and Google Scholar. The search process and identification of articles was carried in the second half of 2020, between September and December.

\subsection{Eligibility Criteria}

Published original research articles on oral health workforce planning were included in the review. Studies need to have followed a workforce modelling approach to estimate the current or future requirements of oral health personnel (dentists, dental specialists, therapists, hygienists, or other allied dental personnel). No restrictions were placed on the type of modelling philosophy, and all studies including supply, demand or needs-based estimates were included. Studies could range from simple dentist population ratios, to more complex skill mix and scenario-based models. Articles published between 2010 and 2020 in English language were included.

Commentaries, reviews, policy briefs, government reports, working papers, opinions, perspectives, conference abstracts, letter to editors, dissertations/thesis, or evidence summaries were excluded in this review. Oral health workforce modelling should have been the main aspect of the paper-studies that only identified oral health workforce requirements without any supporting methods or modelling approaches were excluded. Studies should have also focused on oral health personnel as the basic unit for modelling - studies focusing on dental practices or facilities were excluded.

\subsection{Study Selection}

First, one of the reviewers (S.G.) identified all articles via database searching, duplicates were excluded and imported the final list into a web/mobile based systematic review management application called Rayyan (Qatar Computing Research Institute, Doha, Qatar) [22]. The tool is mainly designed to expedite the initial screening of abstracts, titles and keywords using a process of semi-automation while incorporating a high level of usability [22]. Duplicates were removed. Four reviewers (M.B., A.H., A.A., S.G.) carried out the selection of articles. Articles that did not fit the eligibility criteria were excluded. If 
limited information was available in the initial scanning process, the full text was obtained to determine eligibility. Later, the full text of all selected articles was read, and further limited to only relevant articles based on the selection criteria. Lack of agreement or conflict arising in the selection of articles were resolved through group discussions and consultation with the senior author (J.G.).

\subsection{Data Extraction, Synthesis and Reporting}

Extraction of data from selected papers was performed by using pre-defined criteria. We extracted a range of study characteristics including: author/year, country of research, aim of study, workforce/population modelled, model type, supply/demand/needs models, data sources, findings, strengths/limitations, policy implications and conclusion. All authors were involved in discussing the emerging data to decide on relevance and decide any modifications in the data extraction framework for the study. Data extraction was conducted using an MS Excel template, which was later developed into a MS Access database for improved usability. We followed a descriptive approach in synthesis and reporting of data, based on Khangura et al.'s rapid review methodology [18]. The focus of this paper is limited to detailed characteristics of the supply, demand and needs model, how these models were developed and the sources of data for these models.

\section{Results}

A total of $n=3047$ potential articles were identified through database and citation searching. Following the removal of duplicates, $n=2748$ articles were available for title/abstract/keyword screening. A total of $n=2727$ articles were excluded ( $n=64$ after group discussion and conflict resolution), providing $n=23$ articles for data extraction and qualitative synthesis. Figure 1 provides the PRISMA flowchart of the study selection. A list of selected studies for the rapid review will full citation of articles is provided in Supplementary Table S3.
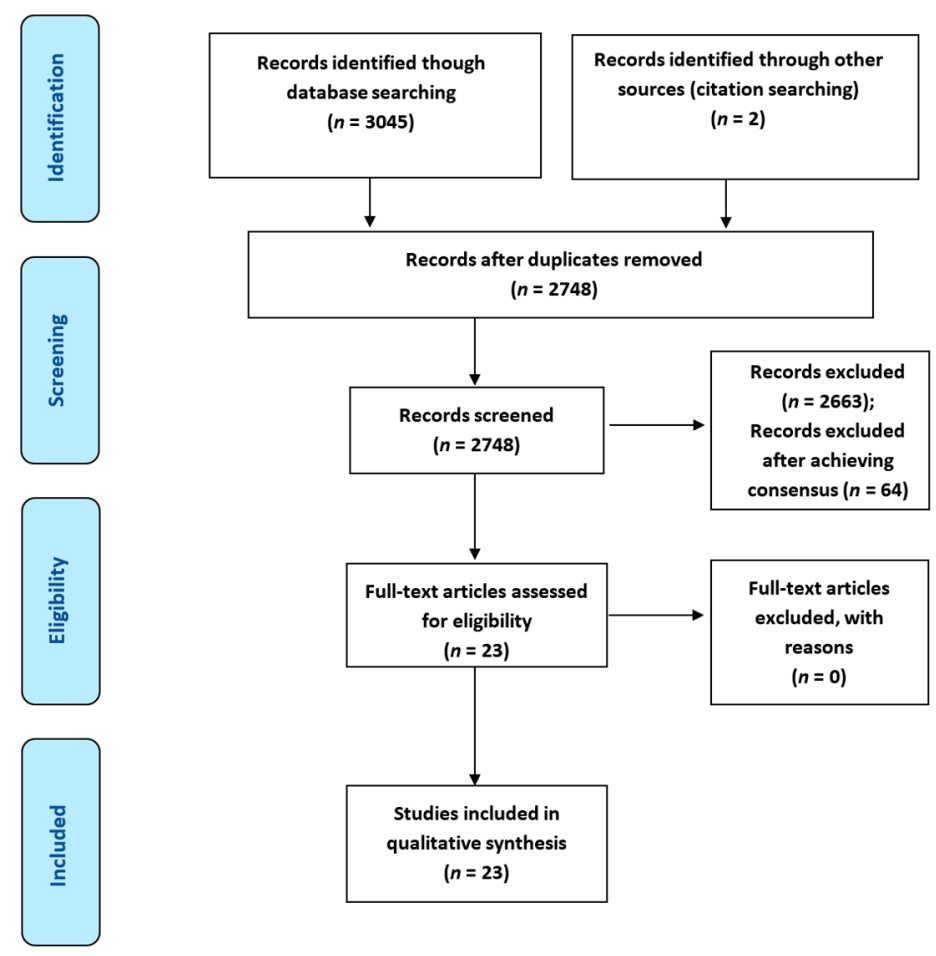

Figure 1. PRISMA Flowchart for the Rapid Review. 


\subsection{Main Study Characteristics}

The main characteristics of the 23 selected studies are provided in Table 1. These publications were from 15 different countries across the world: Australia [23], Canada [24], Chile [25], China [26,27], Japan [28], Kuwait [29], India [30], Ireland [31], Malaysia [32,33], Oman [34], Sri Lanka [35], Taiwan [36], Trinidad \& Tobago [37], the United Kingdom [38-41], and the United States of America [42-45]. Seven studies were based in the WHO American Region, followed by the European $(n=5)$ and Western Pacific Regions $(n=4)$. Most of the studies were also based on high-income group World Bank countries $(n=17)$. It is important to note that no studies were identified from the WHO African Region or lowincome group World Bank countries Dentists were the dominant oral health workforce group modelled across 13 studies [24-31,34-36,43,44]. Five studies considered both dental and allied dental workforce (including therapists, hygienists, clinical technicians, denturists) in the workforce models [32,33,38-40]. Four studies specifically modelled the dental specialist workforce, including all dental specialities [41] or covering any of the limited specialist groups: oral and maxillofacial surgeons [23], orthodontists [37] or pediatric dentists [45]. One study has modelled all three oral health workforce groups: dentists, pediatric dentists (specialists) and dental hygienists (allied dental professionals) [42]. The population being modelled in the studies ranged from the full population of the country/region $(n=10)[23,25,28-30,34-36,40,43]$ or limited to include a specific group such as children $(n=4)[26,37,42,45]$, adults $(n=3)$ [31-33], or older people $(n=1)$ [38]. Four studies focused on population-based at a specific catchment area such as province/state (Liaoning Province, China [27]; Kentucky, USA [44]; Georgia, USA [42]) or a service/administrative zone (South Central Strategic Health Authority, England/UK [39]; Canadian Armed Forces service areas, Canada [24])

A number of workforce modelling types were observed in the selected studies, with the most common application being the workforce to population ratio ( $n=10) \quad[25,27-30,34,36,37,41,44]$ followed by a needs-based/demand-weighted $(n=5)[23,35,38,39,45]$ variant. One article compared both the workforce to population ratio and needs based demand weighted models in the same study [24]. Four studies used a needs-based model [26,31-33]; and three a demand or utilization based model alone $[40,42,43]$.

\subsection{Detailed Study Characteristics}

Table 2 presents detailed study characteristics of the supply, demand and needs models along with various data sources and techniques used in developing these models.

\subsubsection{Supply Models and Data Sources}

A total of 18 studies in the review have presented supply models. Existing stock of the dental workforce has been determined in all these studies, with the most common estimation being through the use of dentist registrations data, obtained via a national dental council or a regulatory authority $(n=7)[29-31,35,38,41,42,44]$. Two studies from the USA have determined estimates using state dental regulatory authorities, namely from Georgia [42] and Kentucky [44]. Brailsford \& De Silva [35], prepared a separate national register for the study accommodating registrations, record matching and panel interview to identify existing stock and currency of practice. Gallagher et al. [38] used a range of sources (registrations, dental practice survey and NHS government data) in determining the existing stock of oral health workforce in England, UK. In addition, four other studies have used mainly dentist surveys in accounting for existing workforce numbers $[23,27,28,43]$. Studies in Australia [23] and Japan [28] have utilized national dental workforce surveys in determining more detailed estimates on the stock of dentists. A few studies have also used government data from sector specific areas such as health services $[36,38,39,42]$ or armed forces [24]. 
Table 1. Main characteristics of selected studies in the rapid review.

\begin{tabular}{|c|c|c|c|c|c|c|}
\hline Study No. & Author(s), Year & Aim of Study & $\begin{array}{l}\text { Country; } \\
\text { WHO Region; } \\
\text { World Bank (WB) } \\
\text { Group }\end{array}$ & $\begin{array}{l}\text { Workforce Group } \\
\text { Modelled }\end{array}$ & Population Modelled & Model Type \\
\hline 1 & Ab-Murat N et al., 2015 & $\begin{array}{l}\text { To compare estimates of periodontal } \\
\text { dental treatment needs and } \\
\text { workforce requirements for } \\
\text { different skill mix models using } \\
\text { normative and sociodental } \\
\text { approaches }\end{array}$ & $\begin{array}{c}\text { Malaysia; } \\
\text { WHO South East Asian } \\
\text { Region; } \\
\text { WB Upper Middle } \\
\text { Income Group }\end{array}$ & $\begin{array}{l}\text { Dentists and Dental } \\
\text { Therapists }\end{array}$ & $\begin{array}{l}\text { Malaysian adults; 30-54 } \\
\text { years old }\end{array}$ & Needs-based \\
\hline 2 & Ab-Murat N et al., 2015 & $\begin{array}{l}\text { To estimate and compare } \\
\text { prosthodontic treatment needs and } \\
\text { workforce requirements, using the } \\
\text { normative and the sociodental } \\
\text { approaches for different skill mix } \\
\text { models }\end{array}$ & $\begin{array}{c}\text { Malaysia; } \\
\text { WHO South East Asian } \\
\text { Region; } \\
\text { WB Upper Middle } \\
\text { Income Group }\end{array}$ & Dentists and Denturists & $\begin{array}{l}\text { Malaysian adults; 30-54 } \\
\text { years old }\end{array}$ & Needs-based \\
\hline 3 & Ahern S et al., 2019 & $\begin{array}{l}\text { To develop a practical oral health } \\
\text { needs based workforce planning } \\
\text { simulation tool and apply it in a } \\
\text { hypothetical situation using } \\
\text { publicly available data in Ireland. }\end{array}$ & $\begin{array}{l}\text { Ireland; } \\
\text { WHO European Region; } \\
\text { WB High Income } \\
\text { Country }\end{array}$ & Dentists & Irish adults; $15+$ years & Needs-based \\
\hline 4 & Al-Jarallah KF et al., 2020 & $\begin{array}{l}\text { To describe the size of the dentist } \\
\text { workforce in Kuwait between } 1994 \\
\text { and 2006, and to project the future } \\
\text { demand for dentists, and supply of } \\
\text { Kuwaiti dentists for the years } \\
\text { 2007-2020 }\end{array}$ & $\begin{array}{c}\text { Kuwait; } \\
\text { WHO Eastern } \\
\text { Mediterranean Region; } \\
\text { WB High Income } \\
\text { Country }\end{array}$ & Dentists & All population in Kuwait & $\begin{array}{c}\text { Workforce to population } \\
\text { ratio }\end{array}$ \\
\hline 5 & Bourne CO, 2012 & $\begin{array}{l}\text { To estimate the current orthodontic } \\
\text { manpower requirements of } \\
\text { Trinidad and Tobago }\end{array}$ & $\begin{array}{l}\text { Trinidad and Tobago; } \\
\text { WHO American Region; } \\
\text { WB High Income } \\
\text { Country }\end{array}$ & Orthodontists & Children; 11 to 12 years & $\begin{array}{l}\text { Workforce to population } \\
\text { ratio }\end{array}$ \\
\hline
\end{tabular}


Table 1. Cont

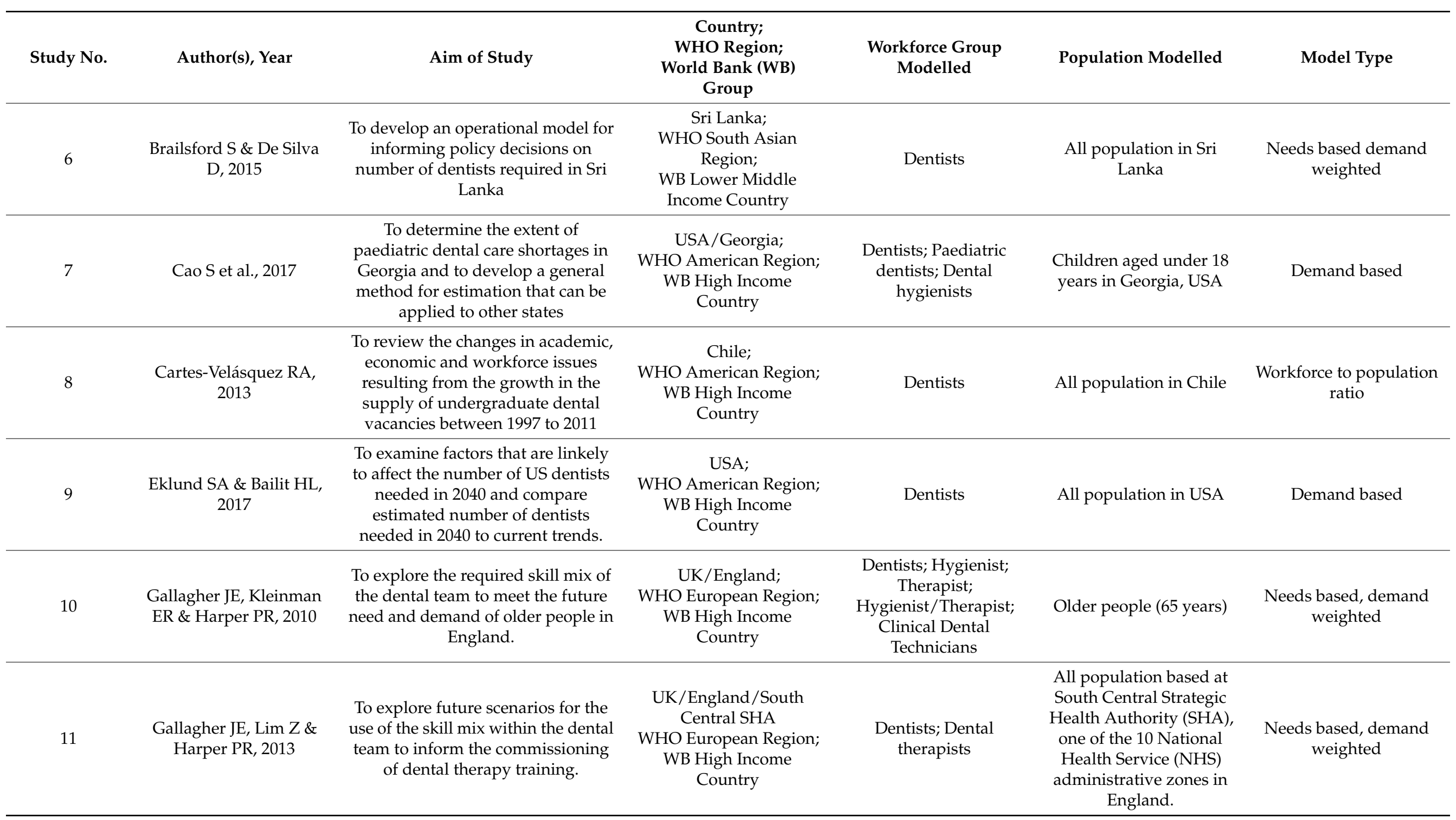


Table 1. Cont.

\begin{tabular}{|c|c|c|c|c|c|c|}
\hline Study No. & Author(s), Year & Aim of Study & $\begin{array}{c}\text { Country; } \\
\text { WHO Region; } \\
\text { World Bank (WB) } \\
\text { Group }\end{array}$ & $\begin{array}{l}\text { Workforce Group } \\
\text { Modelled }\end{array}$ & Population Modelled & Model Type \\
\hline 13 & Huang CS et al., 2013 & $\begin{array}{l}\text { To make projections of the dental } \\
\text { workforce from } 2011 \text { to } 2020 \text {, based } \\
\text { on a survey of the actual workload } \\
\text { of } 6762 \text { dentists in } 2010 .\end{array}$ & $\begin{array}{c}\text { Taiwan; } \\
\text { WHO Western Pacific } \\
\text { Region; } \\
\text { WB High Income } \\
\text { Country }\end{array}$ & Dentists & All population in Taiwan & $\begin{array}{l}\text { Workforce to population } \\
\text { ratio }\end{array}$ \\
\hline 14 & Ishimaru M et al., 2016 & $\begin{array}{l}\text { To estimate the future distribution } \\
\text { of dentists with different working } \\
\text { statuses in Japan and to discuss } \\
\text { policy implications about the } \\
\text { supply of dentists in any country. }\end{array}$ & $\begin{array}{c}\text { Japan; } \\
\text { WHO Western Pacific } \\
\text { Region; } \\
\text { WB High Income } \\
\text { Country }\end{array}$ & Dentists & All population in Japan & $\begin{array}{l}\text { Workforce to population } \\
\text { ratio }\end{array}$ \\
\hline 15 & Jaiswal AK et al., 2014 & $\begin{array}{l}\text { To analyse the changing trends in } \\
\text { dental manpower production in } \\
\text { India since } 1920 \text { and its } \\
\text { development to date, including the } \\
\text { number of dental colleges and } \\
\text { distribution of trained professionals } \\
\text { nationwide. }\end{array}$ & $\begin{array}{l}\text { India; } \\
\text { WHO South Asian } \\
\text { Region; } \\
\text { WB Upper Middle } \\
\text { Income Country }\end{array}$ & Dentists & $\begin{array}{l}\text { All population in India, } \\
\text { broken by } \\
\text { States/Territories. }\end{array}$ & $\begin{array}{l}\text { Workforce to population } \\
\text { ratio }\end{array}$ \\
\hline 16 & Ju X et al., 2010 & $\begin{array}{l}\text { To estimate the supply and demand } \\
\text { of oral and maxillofacial surgeons } \\
\text { and services in Australia }\end{array}$ & $\begin{array}{c}\text { Australia; } \\
\text { WHO Western Pacific } \\
\text { Region; } \\
\text { WB High Income } \\
\text { Country }\end{array}$ & $\begin{array}{l}\text { Oral and Maxillo facial } \\
\text { surgeons }\end{array}$ & $\begin{array}{l}\text { Overall Australian } \\
\text { population }\end{array}$ & $\begin{array}{c}\text { Needs based, demand } \\
\text { weighted }\end{array}$ \\
\hline
\end{tabular}


Table 1. Cont.

\begin{tabular}{|c|c|c|c|c|c|c|}
\hline Study No. & Author(s), Year & Aim of Study & $\begin{array}{c}\text { Country; } \\
\text { WHO Region; } \\
\text { World Bank (WB) } \\
\text { Group }\end{array}$ & $\begin{array}{l}\text { Workforce Group } \\
\text { Modelled }\end{array}$ & Population Modelled & Model Type \\
\hline 17 & Mills RW, 2020 & $\begin{array}{l}\text { To gather data and help contribute } \\
\text { towards assessing the need for } \\
\text { future specialist training places by } \\
\text { mapping General Dental Council } \\
\text { (GDC)-listed specialists registered } \\
\text { in UK postal areas and plotting } \\
\text { specialists' first GDC registration } \\
\text { dates. }\end{array}$ & $\begin{array}{c}\text { UK; } \\
\text { WHO European Region; } \\
\text { WB High Income } \\
\text { Country }\end{array}$ & Dental Specialists & Not available (NA) & $\begin{array}{c}\text { Workforce to population } \\
\text { ratio }\end{array}$ \\
\hline 18 & $\begin{array}{c}\text { Saman DM, Arevalo O \& } \\
\text { Johnson AO, } 2010\end{array}$ & $\begin{array}{l}\text { To assess geographic distribution of } \\
\text { dentists in Kentucky; to estimate the } \\
\text { future availability of dental } \\
\text { providers and provide policy } \\
\text { recommendations so as to improve } \\
\text { access to oral health care in } \\
\text { Kentucky and other rural states }\end{array}$ & $\begin{array}{c}\text { USA/Kentucky; } \\
\text { WHO American Region; } \\
\text { WB High Income } \\
\text { Country }\end{array}$ & Dentists & $\begin{array}{l}\text { All population in } \\
\text { Kentucky, USA }\end{array}$ & $\begin{array}{l}\text { Workforce to population } \\
\text { ratio }\end{array}$ \\
\hline 19 & Shaw JL et al., 2017 & $\begin{array}{l}\text { To compare two methods of } \\
\text { allocating general dentists to } \\
\text { Canadian Armed Forces (CAF) } \\
\text { dental detachments: a } \\
\text { dentist-to-population ratio model } \\
\text { and a needs-based model. }\end{array}$ & $\begin{array}{c}\text { Canada; } \\
\text { WHO American Region; } \\
\text { WB High Income } \\
\text { Country }\end{array}$ & Dentists & $\begin{array}{l}\text { Canadian Armed Forces } \\
\text { population in catchment } \\
\text { areas }\end{array}$ & $\begin{array}{l}\text { Workforce to population } \\
\text { ratio }\end{array}$ \\
\hline 20 & Sun X et al., 2017 & $\begin{array}{c}\text { To estimate the required human } \\
\text { resources to meet the oral health } \\
\text { needs of the WHO reference group } \\
\text { of } 12 \text {-year-olds in China and } \\
\text { consider the implications for } \\
\text { education, practice, policy and } \\
\text { Human Resources for Oral Health } \\
\text { nationally }\end{array}$ & $\begin{array}{c}\text { China; } \\
\text { WHO Western Pacific } \\
\text { Region; } \\
\text { WB Upper Middle } \\
\text { Income Country }\end{array}$ & Dentists & Children; 12 year olds & Needs based \\
\hline
\end{tabular}


Table 1. Cont.

\begin{tabular}{|c|c|c|c|c|c|c|}
\hline Study No. & Author(s), Year & Aim of Study & $\begin{array}{c}\text { Country; } \\
\text { WHO Region; } \\
\text { World Bank (WB) } \\
\text { Group }\end{array}$ & $\begin{array}{l}\text { Workforce Group } \\
\text { Modelled }\end{array}$ & Population Modelled & Model Type \\
\hline 22 & Wanyonyi KL et al., 2015 & $\begin{array}{l}\text { To investigate the potential for skill } \\
\text { mix use in primary dental care in } \\
\text { England based on the } \\
\text { undergraduate training experience } \\
\text { in a primary care team training } \\
\text { centre for dentists and mid-level } \\
\text { dental providers }\end{array}$ & $\begin{array}{c}\text { UK/England; } \\
\text { WHO European Region; } \\
\text { WB High Income } \\
\text { Country }\end{array}$ & $\begin{array}{l}\text { Dentists; Dental } \\
\text { therapists }\end{array}$ & $\begin{array}{l}\text { All population (adults } \\
\text { and children) in England, } \\
\text { who avail NHS public } \\
\text { dental care. }\end{array}$ & Demand based \\
\hline 23 & Zhang Y et al., 2015 & $\begin{array}{l}\text { To describe the distribution, } \\
\text { structure and allocation of oral } \\
\text { health services personnel, evaluate } \\
\text { oral health service capacity and } \\
\text { predict the future needs for oral } \\
\text { health services in northern China. }\end{array}$ & $\begin{array}{c}\text { China; } \\
\text { WHO Western Pacific } \\
\text { Region; } \\
\text { WB Upper Middle } \\
\text { Income Country }\end{array}$ & Dentists & $\begin{array}{c}\text { All population based at } \\
\text { Liaoning Province, } \\
\text { China }\end{array}$ & $\begin{array}{l}\text { Workforce to population } \\
\text { ratio }\end{array}$ \\
\hline
\end{tabular}


Table 2. Detailed characteristics of supply and demand/needs model of selected studies.

\begin{tabular}{|c|c|c|c|c|c|c|}
\hline \multirow[t]{2}{*}{$\begin{array}{l}\text { Study } \\
\text { No. }\end{array}$} & \multirow[t]{2}{*}{$\begin{array}{c}\text { Author(s), } \\
\text { Year }\end{array}$} & \multicolumn{2}{|c|}{ Supply Model } & \multicolumn{2}{|l|}{ Demand I Needs Model } & \multirow{2}{*}{$\begin{array}{c}\text { Modelling Technique } \\
\\
\text { Approach } \\
\text { Skill mix }\end{array}$} \\
\hline & & $\begin{array}{c}\text { Existing Stock; } \\
\text { Flows; } \\
\text { Newly trained; } \\
\text { Workforce } \\
\text { participation/Full } \\
\text { Time Equivalent (FTE) }\end{array}$ & Data source(s) & $\begin{array}{c}\text { Population; } \\
\text { Demand I Needs } \\
\text { Workforce requirement }\end{array}$ & Data source(s) & \\
\hline 1 & $\begin{array}{l}\text { Ab-Murat } \\
\text { N et al., } \\
2015\end{array}$ & NA & NA & $\begin{array}{l}\text { Population: } 30-54 \text { year old adults; employees at a } \\
\text { public university in Kuala Lumpur, Malaysia ( } n=732) \\
\text { Needs: Periodontal treatment needs assessed using } \\
\text { Normative and Social Dental Approaches. } \\
\text { - } \quad \text { Normative Needs (NN) assessed using } \\
\text { Community Periodontal Index, where presence of } \\
\text { bleeding, calculus and pockets recorded for all } \\
\text { indexed teeth. } \\
\text { Socio-Dental Need (SDA) assessed for people } \\
\text { with NN. Impact Related Need and Propensity } \\
\text { Related Need accounted for quality of life and } \\
\text { behavioural assessment respectively in estimating } \\
\text { treatment needs. } \\
\text { Workforce requirement: Timings for periodontal } \\
\text { procedures were used to estimate dental personnel } \\
\text { required for both above approaches. Timings and } \\
\text { dental personnel were estimated for 100,000 people to } \\
\text { make inferences to all adults in Malaysia. }\end{array}$ & $\begin{array}{l}\text { Oral health clinical } \\
\text { examination of sample to } \\
\text { assess oral health status } \\
\text { and periodontal conditions. } \\
\text { Face to face questionnaire } \\
\text { survey to assess impacts } \\
\text { on oral health related } \\
\text { quality of life, } \\
\text { frequency/severity of } \\
\text { impacts, and oral health } \\
\text { behaviours. } \\
\text { Expert committee } \\
\text { consisting of } 6 \text { dentists } \\
\text { reviewed periodontal } \\
\text { procedures and } \\
\text { determined minimum and } \\
\text { maximum times for } \\
\text { periodontal treatments. } \\
\text { The annual working hours } \\
\text { of } 1760 \text { was used to } \\
\text { highlight the differences in } \\
\text { workforce estimates } \\
\text { between the different } \\
\text { scenarios }\end{array}$ & $\begin{array}{l}\text { Approach: Dental personnel } \\
\text { requirements for both NN and } \\
\text { SDA estimated and compared } \\
\text { using statistical tests. } \\
\text { Comparisons made } \\
\text { accounting for minimum and } \\
\text { maximum treatment times, } \\
\text { and dental personnel required } \\
\text { for 100,000 Malaysian adults. } \\
\text { Skill mix: Treatment timings } \\
\text { for dentists and therapists } \\
\text { were taken to be similar. Three } \\
\text { scenarios modelled to meet } \\
\text { periodontal care under the NN } \\
\text { and SDA approaches: } \\
\text { - } \quad \text { Dentist only; } \\
\text { - Minimum skill mix (only } \\
\quad \text { scaling and polishing } \\
\text { delegated to therapists); } \\
\text { Maximum skill mix } \\
\text { (scaling, polishing and } \\
\text { root planning procedures } \\
\text { delegated to dental } \\
\text { therapists; dentists carry } \\
\text { periodontal surgery) }\end{array}$ \\
\hline
\end{tabular}


Table 2. Cont.

\begin{tabular}{|c|c|c|c|c|c|c|}
\hline $\begin{array}{l}\text { Study } \\
\text { No. }\end{array}$ & $\begin{array}{c}\text { Author(s), } \\
\text { Year }\end{array}$ & & Supply Model & Demand I Needs Model & & Modelling Technique \\
\hline 2 & $\begin{array}{c}\text { Ab-Murat } \\
\text { N et al., } \\
2015\end{array}$ & NA & NA & $\begin{array}{l}\text { Population: } 30-54 \text { year old adults; employees at a } \\
\text { public university in Kuala Lumpur, Malaysia }(n=732) \\
\text { Needs: Prosthodontic treatment needs assessed using } \\
\text { Normative and Social Dental Approaches. } \\
\text { - } \quad \begin{array}{l}\text { Normative Needs (NN) based on missing teeth, } \\
\text { ill-fitting or non-aesthetic prosthesis. }\end{array} \\
\text { - Socio-Dental Need (SDA) assessed for people } \\
\text { with NN. Impact Related Need measured via an } \\
\text { oral impact for daily performance index. } \\
\quad \text { Propensity Related Need i.e., behavioural } \\
\quad \text { assessment for people who were in need of } \\
\text { bridges or dentures } \\
\text { Workforce requirement: Timings for prosthodontic } \\
\text { treatment were used to estimate dental personnel } \\
\text { required for both above approaches. Timings and } \\
\text { dental personnel were estimated for 100,000 people to } \\
\text { make inferences to all adults in Malaysia. }\end{array}$ & $\begin{array}{l}\text { Oral health clinical } \\
\text { examination of sample to } \\
\text { assess oral health status } \\
\text { including missing teeth, } \\
\text { requirement of dentures or } \\
\text { any prosthodontic } \\
\text { treatment } \\
\text { Face to face questionnaire } \\
\text { survey to assess impacts } \\
\text { on oral health related } \\
\text { quality of life, } \\
\text { frequency/severity of } \\
\text { impacts, and oral health } \\
\text { behaviours. } \\
\text { Expert committee } \\
\text { consisting of } 6 \text { dentists } \\
\text { reviewed prosthodontic } \\
\text { treatments for dentures } \\
\text { and bridges, determined } \\
\text { minimum and maximum } \\
\text { times for periodontal } \\
\text { treatments, } 1760 \text { annual } \\
\text { working hours. }\end{array}$ & $\begin{array}{l}\text { Approach: Dental personnel } \\
\text { requirements for both NN and } \\
\text { SDA estimated and compared } \\
\text { using statistical tests. } \\
\text { Comparisons made } \\
\text { accounting for minimum and } \\
\text { maximum treatment times, } \\
\text { and dental personnel required } \\
\text { for 100,000 Malaysian adults. } \\
\text { Skill mix: Treatment timings } \\
\text { for dentists and denturists } \\
\text { were taken to be similar. Three } \\
\text { scenarios modelled to meet } \\
\text { prosthodontic care under the } \\
\text { NN and SDA approaches: } \\
\text { - Dentist only; } \\
\text { - Minimum skill mix } \\
\text { (denturists provide only } \\
\text { complete dentures); } \\
\text { Maximum skill mix } \\
\text { (denturists can provide } \\
\text { all denture procedures } \\
\text { except bridges) }\end{array}$ \\
\hline
\end{tabular}


Table 2. Cont.

\begin{tabular}{|c|c|c|c|c|c|c|}
\hline Study No. & $\begin{array}{c}\text { Author(s), } \\
\text { Year }\end{array}$ & \multicolumn{2}{|l|}{ Supply Model } & \multicolumn{2}{|l|}{ Demand I Needs Model } & Modelling Technique \\
\hline 3 & $\begin{array}{c}\text { Ahern S et al., } \\
2019\end{array}$ & $\begin{array}{l}\text { Existing stock: Stock of dentists } \\
\text { in Ireland was estimated using } \\
\text { registration statistics, which } \\
\text { included information such as } \\
\text { date of registration, year of } \\
\text { qualification and primary } \\
\text { qualification. } \\
\text { Flows: Inflows were based on } \\
\text { three types: } \\
\text { - Overseas-trained dentists } \\
\quad \text { newly registered to } \\
\quad \text { practice } \\
\quad \text { Irish trained dentists } \\
\quad \text { returning to practice } \\
\quad \text { Dentists returning after a } \\
\text { period of absence } \\
\text { Outflows were based on three } \\
\text { types: } \\
\quad \text { Dentists leaving Ireland } \\
\text { - Dentists taking career } \\
\quad \text { break or period of absence } \\
\text { Retirement and death } \\
\text { Newly trained: Number of } \\
\text { undergraduate places in the two } \\
\text { dental schools, adjusted for } \\
\text { attrition/failure rate. Then, the } \\
\text { number is adjusted to account } \\
\text { for the percentage } \\
\text { entering employment. } \\
\text { Workforce participation/FTE: } \\
\text { Participation rate assumed at } \\
95 \% \text { of all dentists registered, to } \\
\text { account for dentists working in } \\
\text { non-clinical activity. Further, } \\
\text { activity rate was assumed to be } \\
\text { at } 85 \% \text { accounting for part time } \\
\text { work. All supply, inflow and } \\
\text { outflow estimates were adjusted } \\
\text { to reflect this activity rate. }\end{array}$ & $\begin{array}{l}\text { Registration data } \\
\text { of dentists from } \\
\text { Dental Council of } \\
\text { Ireland } \\
\text { Registration data } \\
\text { of dentists from } \\
\text { Dental Council of } \\
\text { Ireland } \\
\text { Dental Schools } \\
\text { Data }\end{array}$ & $\begin{array}{l}\text { Population: Adult population of Ireland (15+ years). } \\
\text { Age and gender distributions available. } \\
\text { Needs: Oral health status mainly identified from four } \\
\text { questions used in the population survey: } \\
-\quad \text { Number of teeth present } \\
-\quad \text { How often in past } 12 \text { months one has experienced } \\
\text { difficulty in: }\end{array}$ & $\begin{array}{l}\text { Special Eurobarometer } 330 \\
\text { Oral Health Survey dataset } \\
\text { Special Eurobarometer } 330 \\
\text { Oral Health Survey dataset } \\
\text { Special Eurobarometer } 330 \\
\text { Oral Health Survey dataset }\end{array}$ & 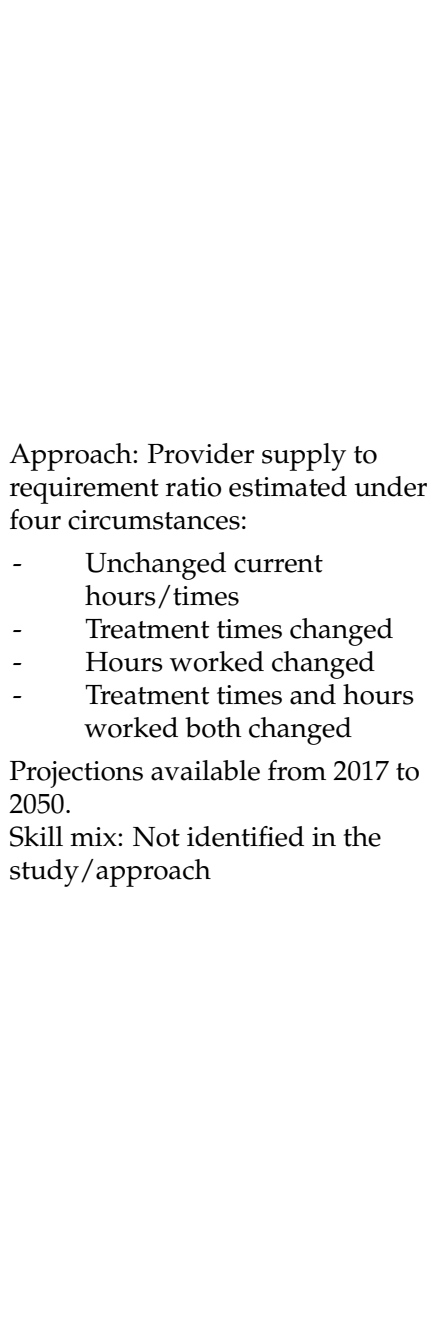 \\
\hline
\end{tabular}


Table 2. Cont

\begin{tabular}{|c|c|c|c|c|c|c|}
\hline $\begin{array}{l}\text { Study } \\
\text { No. }\end{array}$ & $\begin{array}{c}\text { Author(s), } \\
\text { Year }\end{array}$ & \multicolumn{2}{|c|}{ Supply Model } & \multicolumn{2}{|l|}{ Demand I Needs Model } & Modelling Technique \\
\hline 4 & $\begin{array}{l}\text { Al-Jarallah } \\
\text { KF et al. } \\
2020\end{array}$ & $\begin{array}{l}\text { Existing stock Dentist } \\
\text { estimates based on } \\
\text { registrations data. } \\
\text { Workforce } \\
\text { participation/FTE: } \\
\text { Dentist numbers } \\
\text { (Kuwaiti and Non } \\
\text { Kuwaiti) were used as } \\
\text { proxy for workforce } \\
\text { participation. }\end{array}$ & $\begin{array}{l}\text { Dental } \\
\text { Licensing } \\
\text { Department; } \\
\text { Ministry of } \\
\text { Health Kuwait; } \\
\text { Ministry of } \\
\text { Planning } \\
\text { Kuwait; Faculty } \\
\text { of Dentistry, } \\
\text { Kuwait }\end{array}$ & $\begin{array}{l}\text { Population: Overall population of Kuwait was } \\
\text { considered, including projections. }\end{array}$ & $\begin{array}{l}\text { Ministry of Health Kuwait; } \\
\text { Ministry of Planning } \\
\text { Kuwait; Department of } \\
\text { Statistics and Medical } \\
\text { Records, Kuwait }\end{array}$ & $\begin{array}{l}\text { Approach: Dentist supply } \\
\text { numbers available from } 1994 \\
\text { to 2006, and were projected for } \\
\text { years } 2007 \text { to 2020. Similarly, } \\
\text { population estimates were also } \\
\text { available/projected for the } \\
\text { given years. } \\
\text { Projected supply estimates } \\
\text { and dentist to population } \\
\text { ratios accounted for growth in } \\
\text { previous years. } \\
\text { Shortfall in Kuwaiti dentists } \\
\text { (based on annual increase } \\
\text { estimates) to overall dentists } \\
\text { (based on dentist to } \\
\text { population ratio estimates) } \\
\text { was projected for the years } \\
2007 \text { to 2020. } \\
\text { Skill mix: Not identified in the } \\
\text { study/approach }\end{array}$ \\
\hline 5 & $\begin{array}{l}\text { Bourne CO, } \\
2012\end{array}$ & NA & NA & $\begin{array}{l}\text { Population: } 11-12 \text { year old childrenDemand: } \\
\text { Orthodontic treatment preferences and visits of } \\
\text { children were estimated through a population survey. } \\
\text { Unclear how total children requiring orthodontic } \\
\text { treatment were estimated. } \\
\text { Workforce requirement: } 9 \text { orthodontists from } 11 \\
\text { practices, who have been in practice for } 10+\text { years and } \\
\text { practice established } 5 \text { years ago were surveyed using a } \\
\text { workforce questionnaire. Number of patients treated } \\
\text { per year was estimated. Unclear how workforce } \\
\text { requirements were limited to the specific age group } \\
\text { 11-12 years. }\end{array}$ & $\begin{array}{l}\text { Cross sectional study on } \\
\text { orthodontic treatment } \\
\text { needs of 11-12 years old } \\
\text { children. } \\
\text { Questionnaire survey } \\
\text { administered to all } \\
\text { orthodontists }\end{array}$ & $\begin{array}{l}\text { Approach: Gap in total } \\
\text { number of orthodontics } \\
\text { required and currently } \\
\text { available was identified } \\
\text { though a survey based } \\
\text { approach. Modelling aspects } \\
\text { from the survey findings and } \\
\text { how it applies to the specific } \\
\text { age group is unclear in the } \\
\text { description. } \\
\text { A broad orthodontists to } \\
\text { children/population approach } \\
\text { seems to have applied for } \\
\text { modelling. } \\
\text { Skill mix: Not identified in the } \\
\text { study/approach }\end{array}$ \\
\hline
\end{tabular}


Table 2. Cont

\begin{tabular}{|c|c|c|c|c|c|c|}
\hline $\begin{array}{l}\text { Study } \\
\text { No. }\end{array}$ & $\begin{array}{l}\text { Author(s), } \\
\text { Year }\end{array}$ & \multicolumn{2}{|c|}{ Supply Model } & \multicolumn{2}{|l|}{ Demand I Needs Model } & Modelling Technique \\
\hline 6 & $\begin{array}{c}\text { Brailsford S } \\
\text { \& De Silva } \\
\text { D, } 2015\end{array}$ & $\begin{array}{l}\text { Existing stock: A national } \\
\text { register of practising } \\
\text { dentists natively prepared } \\
\text { using dental registrations } \\
\text { from medical council, } \\
\text { record matching and panel } \\
\text { interviews. Practice } \\
\text { activity of dentists } \\
\text { Flows: Attrition, } \\
\text { Retirement and migration } \\
\text { were accounted for in the } \\
\text { model. } \\
\text { Newly trained: Newly } \\
\text { trained dentist practices } \\
\text { based on outputs of the } \\
\text { single dental school in Sri } \\
\text { Lanka. Students were also } \\
\text { surveyed on motivations } \\
\text { and career expectations. } \\
\text { Workforce } \\
\text { participation/FTE: Practice } \\
\text { activity of dentists } \\
\text { surveyed via postal } \\
\text { questionnaire, collecting } \\
\text { information on } \\
\text { socio-demographics, } \\
\text { working patterns, hours } \\
\text { worked, practice location, } \\
\text { and main practice type. } \\
\text { Total available clinical } \\
\text { hours was estimated. }\end{array}$ & $\begin{array}{l}\text { Sri Lankan } \\
\text { Medical } \\
\text { Council } \\
\text { Registrations; } \\
\text { Panel } \\
\text { interviews; } \\
\text { Dental practice } \\
\text { activity survey } \\
\text { Student survey }\end{array}$ & $\begin{array}{l}\text { Population: All people in Sri Lanka } \\
\text { Demand: FDI/WHO method for estimating } \\
\text { services needed for a person, expressed in minutes, } \\
\text { is used. Dental disease burden is accounted for in } \\
\text { three main categories: caries, periodontal disease, } \\
\text { and prosthodontic treatment needs. Local advice } \\
\text { sought to identity percentage of people who need } \\
\text { care, and who actively express demand for care. } \\
\text { Workforce requirement: Timings for dental } \\
\text { treatment were estimated via a survey, and } \\
\text { treatment times were scaled up for each age groups, } \\
\text { and at national level to identify the number of } \\
\text { overall treatment hours required. }\end{array}$ & $\begin{array}{l}\text { Sri Lankan Department of } \\
\text { Census and Statistics } \\
2003 \text { National Oral Health } \\
\text { Survey, Sri Lankan } \\
\text { Ministry of Health }\end{array}$ & $\begin{array}{l}\text { Approach: Supply and } \\
\text { demands models separately } \\
\text { created with the outputs of } \\
\text { both models being number of } \\
\text { hours available or required. } \\
\text { Both these models were } \\
\text { superimposed to identify gap } \\
\text { in provision of services in } \\
\text { treatment hours and number } \\
\text { of dentists. } \\
\text { A range of supply and } \\
\text { demand scenarios were } \\
\text { modelled for the years } 2010 \text { to } \\
\text { 2024. Demand was considered } \\
\text { in three main scenarios: low, } \\
\text { moderate and high (in hours), } \\
\text { and supply estimates were } \\
\text { varied based on student } \\
\text { intakes, retirements, practice } \\
\text { activity restrictions, private } \\
\text { sector participation and } \\
\text { increased employment } \\
\text { opportunities. } \\
\text { Skill mix: Not identified in the } \\
\text { study/approach }\end{array}$ \\
\hline
\end{tabular}


Table 2. Cont.

\begin{tabular}{|c|c|c|c|c|c|c|}
\hline $\begin{array}{l}\text { Study } \\
\text { No. }\end{array}$ & $\begin{array}{l}\text { Author(s), } \\
\text { Year }\end{array}$ & \multicolumn{2}{|c|}{ Supply Model } & \multicolumn{2}{|l|}{ Demand I Needs Model } & Modelling Technique \\
\hline 7 & $\begin{array}{c}\text { Cao S et al., } \\
2017\end{array}$ & $\begin{array}{l}\text { Existing stock: } \\
\text { Number of dental } \\
\text { registrations available } \\
\text { from local/state } \\
\text { government sources. } \\
\text { Flows: Not identified } \\
\text { in the study/approach } \\
\text { Newly trained: Not } \\
\text { identified in the } \\
\text { study/approach } \\
\text { Workforce } \\
\text { participation/FTE: } \\
\text { Average work hours of } \\
35.2 \text { and } 35.6 \text { h } \\
\text { accounted for male and } \\
\text { female dentists per } \\
\text { week. Time spend for } \\
\text { the provision of } \\
\text { paediatric dental care } \\
\text { was estimated for both } \\
\text { general dentists at } 22 \% \\
\text { and paediatric dentists } \\
\text { at } 84 \% \text {. This provided } \\
\text { overall clinical hours } \\
\text { available for treating } \\
\text { children. }\end{array}$ & $\begin{array}{l}2015 \text { National } \\
\text { Plan and } \\
\text { Provider } \\
\text { Enumeration } \\
\text { System } \\
\text { Georgia Board } \\
\text { of Dentistry } \\
\text { roster for } \\
\text { licenses } \\
\text { expiring } \\
\text { 2010 Survey of } \\
\text { Dental Practice }\end{array}$ & $\begin{array}{l}\text { Population: All children in Georgia, USA } \\
\text { Demand: Caries risk estimated for children using } \\
\text { survey data and prevalence of high risk and low risk } \\
\text { children estimated across each census tract (geographic } \\
\text { areas). } \\
\text { Workforce requirement: Dental care demand per child } \\
\text { by age group (0-3, } 4-5,6-7 \text { and } 8-18 \text { years) estimated } \\
\text { in minutes, and stratified by caries risk. Published data } \\
\text { on procedure timings (including MEPS and expert } \\
\text { opinions) were used to estimate paediatric treatment } \\
\text { need. The timings were estimated for state and each } \\
\text { geographic area/county. }\end{array}$ & $\begin{array}{l}2010 \text { US Census data } \\
\text { National Health and } \\
\text { Nutrition Examination } \\
\text { Survey data } \\
\text { Medical Expenditure Panel } \\
\text { Survey } \\
\text { Expert opinion for } \\
\text { treatment timings }\end{array}$ & $\begin{array}{l}\text { Approach: Paediatric work } \\
\text { hours were estimated both on } \\
\text { supply side and demand side, } \\
\text { and superimposed at the } \\
\text { geographic level (country) to } \\
\text { understand shortage areas. } \\
\text { Skill mix: Dental hygienists, } \\
\text { general dentists accounted for } \\
\text { in the calculation of work } \\
\text { hours along with paediatric } \\
\text { dentists. }\end{array}$ \\
\hline
\end{tabular}


Table 2. Cont.

\begin{tabular}{|c|c|c|c|c|c|c|}
\hline $\begin{array}{l}\text { Study } \\
\text { No. }\end{array}$ & $\begin{array}{c}\text { Author(s), } \\
\text { Year }\end{array}$ & Supply Model & & \multicolumn{2}{|c|}{ Demand I Needs Model } & Modelling Technique \\
\hline 8 & $\begin{array}{l}\text { Cartes- } \\
\text { Velásquez } \\
\text { RA, } 2013\end{array}$ & $\begin{array}{l}\text { Existing stock: Current workforce } \\
\text { (baseline: 2012) estimated at } n= \\
17,000 \text { dentists. Historical data on } \\
\text { number of dentists and graduates } \\
\text { available from } 1997 \text { to } 2011 \text {. } \\
\text { Flows: Dentist migration and attrition } \\
\text { rates were not included in the model. } \\
\text { Newly trained: Current number of } \\
\text { dental schools and graduates } \\
\text { accounted for. Assumptions made } \\
\text { that } 80 \% \text { of students in school } \\
\text { graduate. Opening of new dental } \\
\text { schools not accounted for. } \\
\text { Workforce participation/FTE: } \\
\text { Number of dentists available in the } \\
\text { workforce was estimated based on the } \\
\text { available assumptions at 2012, mainly } \\
\text { accounting for student graduations. } \\
\text { Unclear if any historical data from } \\
\text { previous years were used to inform } \\
\text { the supply projection model. }\end{array}$ & $\begin{array}{l}\text { Indicadores de } \\
\text { Instituciones y } \\
\text { Carreras de } \\
\text { Edu- cación } \\
\text { Superior } \\
\text { database of the } \\
\text { Consejo } \\
\text { Nacional de } \\
\text { Educación } \\
\text { (Education } \\
\text { database from } \\
\text { the Ministry of } \\
\text { Education, } \\
\text { Chile) }\end{array}$ & Population: Total population in Chile. & $\begin{array}{l}\text { Instituto Nacional de Es- } \\
\text { tadísticas de Chile } \\
\text { (National Statistics } \\
\text { Department of Chile) }\end{array}$ & $\begin{array}{l}\text { Approach: Workforce to } \\
\text { population ratios were } \\
\text { estimated, and gap in dentist } \\
\text { numbers and dentist to } \\
\text { population ratios were } \\
\text { visually described. } \\
\text { Historical trends on dental } \\
\text { school enrolments and dentist } \\
\text { numbers also provided on the } \\
\text { supply model.Skill mix: Not } \\
\text { identified in the } \\
\text { study/approach }\end{array}$ \\
\hline 9 & $\begin{array}{l}\text { Eklund SA } \\
\text { \& Bailit HL, } \\
2017\end{array}$ & $\begin{array}{l}\text { Existing stock: Number of dentists ( } n \\
=195,722) \text { in USA working across } \\
\text { private practices, armed forces, } \\
\text { hospitals, resident students or others } \\
\text { were identified from a survey. } \\
\text { Flows: Not identified in the } \\
\text { study/approach } \\
\text { Newly trained: Not identified in the } \\
\text { study/approach } \\
\text { Workforce participation/FTE: } 70 \% \text { of } \\
\text { all dentists assumed to provide full } \\
\text { time care }(n=136,905) \text { at } 30 \text { or more } \\
\text { hours per week. }\end{array}$ & $\begin{array}{l}\text { American } \\
\text { Dental } \\
\text { Association } \\
\text { Survey Centre }\end{array}$ & $\begin{array}{l}\text { Population: Overall population for } \\
\text { current year (2015) and projections for } \\
2040 \text { available. } \\
\text { Demand: Previous publications suggest } \\
\text { about } 42 \text { to } 62 \% \text { of people visit dentist } \\
\text { once every year, estimated at } 135 \text { to } 215 \\
\text { million single dental visits. } \\
\text { Workforce requirement: Based on the } \\
\text { number of dental visits, dentist } \\
\text { requirements are estimated. }\end{array}$ & $\begin{array}{l}\text { National Centre for Health } \\
\text { Statistics } \\
\text { Previous publications } \\
\text { (Manski et al. 2009, 2016) }\end{array}$ & $\begin{array}{l}\text { Approach: Number of FTE } \\
\text { dentists available under the } \\
\text { supply model and number of } \\
\text { FTE dentists required under } \\
\text { the demand model were } \\
\text { estimated and compared. } \\
\text { A range of theoretical } \\
\text { assumptions and policy } \\
\text { approaches were discussed, } \\
\text { but without a modelling } \\
\text { exercise. } \\
\text { Skill mix: Not identified in the } \\
\text { study/approach }\end{array}$ \\
\hline
\end{tabular}


Table 2. Cont.

\begin{tabular}{|c|c|c|c|c|c|c|}
\hline $\begin{array}{c}\text { Study } \\
\text { No. }\end{array}$ & $\begin{array}{c}\text { Author(s), } \\
\text { Year }\end{array}$ & \multicolumn{2}{|l|}{ Supply Model } & \multicolumn{2}{|l|}{ Demand I Needs Model } & \multirow[b]{2}{*}{$\begin{array}{l}\quad \text { Modelling Technique } \\
\text { Approach: Workforce/FTE } \\
\text { estimates were calculated } \\
\text { using both the supply and } \\
\text { demand models, and } \\
\text { superimposition of both } \\
\text { models identified shortage or } \\
\text { surplus. } \\
\text { Sensitivity analysis was done } \\
\text { via Monte Carlo simulation } \\
\text { and linear programming } \\
\text { models. Estimates were } \\
\text { projected from 2006 (baseline) } \\
\text { to 2028. } \\
\text { Skill mix: Various skill mix } \\
\text { scenarios included that took } \\
\text { into account the type of } \\
\text { treatments provided by } \\
\text { dentists and } \\
\text { therapists/hygienists and FTE } \\
\text { contribution (and costs). Five } \\
\text { scenarios used: } \\
\text { - Evolving skill mix } \\
\text { - No skill mix } \\
\text { - } \\
\text { Hygenists/therapists } \\
\text { expand tasks to include } \\
\text { dental exams } \\
\text { Clinical Dental } \\
\text { Technicians (CDTs) } \\
\text { provide all dentures } \\
\text { Maximum skill mix, with } \\
\text { expanded roles for } \\
\text { hygienists/therapists } \\
\text { and CDTs }\end{array}$} \\
\hline 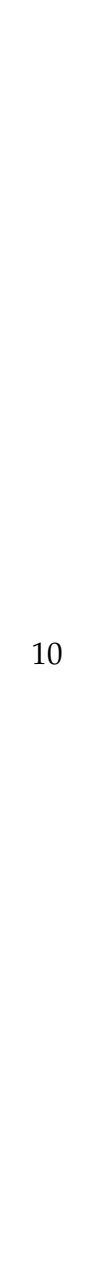 & $\begin{array}{l}\text { Gallagher } \\
\text { JE, } \\
\text { Kleinman } \\
\text { ER \& } \\
\text { Harper PR, } \\
2010\end{array}$ & $\begin{array}{l}\text { Existing Stock: Supply of } \\
\text { dentists, hygienists and } \\
\text { therapists (2006: baseline) } \\
\text { determined from registrations, } \\
\text { survey and NHS data. The } \\
\text { shift to dual qualified } \\
\text { hygienists and therapists } \\
\text { included, with a gradual } \\
\text { increase in hygienist numbers. } \\
\text { Flows: Short term recruitment } \\
\text { drive }(n=1000 \text { dentists) } \\
\text { included; Unclear to what } \\
\text { extent migration, attrition and } \\
\text { return to work is incorporated. } \\
\text { Newly trained: Current } \\
\text { student completions, as well } \\
\text { as increases in student intake } \\
\text { for dentists ( } n=170 \text { ) and } \\
\text { dental hygienists/therapists } \\
\text { training ( } n=150 \text { ) } \\
\text { accommodated. } \\
\text { Workforce participation/FTE: } \\
\text { Percentage of care provided } \\
\text { for older people at NHS was } \\
\text { estimated at } 14 \% \text { of all activity } \\
\text { data. NHS FTE\% for dentists } \\
\text { was based on } 69 \% \text { of } \\
\text { registrations, converting GDC } \\
\text { register headcount to } \\
\text { practising FTE dentists. NHS } \\
\text { FTE for therapists / hygienists } \\
\text { was assumed to be at } 80 \% \text { of } \\
\text { NHS FTE of dentists. }\end{array}$ & $\begin{array}{l}\text { Dental Practice } \\
\text { Board of NHS } \\
\text { England and } \\
\text { Wales for old } \\
\text { General Dental } \\
\text { Services (GDS) } \\
\text { and old } \\
\text { Personal Dental } \\
\text { Services (PDS); } \\
\text { Primary Care } \\
\text { Health } \\
\text { Workforce } \\
\text { Survey; } \\
\text { General Dental } \\
\text { Council } \\
\text { Registrations }\end{array}$ & $\begin{array}{l}\text { Population: Older people in England UK, aged } \\
65 \text { to } 99 \text { years. } \\
\text { Demand: Population demographics (age, sex), } \\
\text { oral health status (edentate rates), participation } \\
\text { and attendance in NHS, and treatments } \\
\text { provided included to estimate demand in terms } \\
\text { of dentate and edentate treatments. Treatment } \\
\text { rates, treatment times and costs were also } \\
\text { accommodated for the services provided. } \\
\text { Workforce requirement: Total demand was } \\
\text { estimated in terms of treatment time (and } \\
\text { cost)—also used in determining the FTE } \\
\text { dentists and therapists/hygienists required. }\end{array}$ & $\begin{array}{l}\text { UK Adult Dental Survey; } \\
\text { The Information Centre } \\
\text { UK; } \\
\text { UK Government Actuary's } \\
\text { Department } \\
\text { Treatment times from the } \\
\text { British Dental Association }\end{array}$ & \\
\hline
\end{tabular}


Table 2. Cont

\begin{tabular}{|c|c|c|c|c|c|c|}
\hline $\begin{array}{l}\text { Study } \\
\text { No. }\end{array}$ & $\begin{array}{l}\text { Author(s), } \\
\text { Year }\end{array}$ & \multicolumn{2}{|c|}{ Supply Model } & \multicolumn{2}{|l|}{ Demand I Needs Model } & Modelling Technique \\
\hline 11 & $\begin{array}{c}\text { Gallagher } \\
\text { JE, Lim Z \& } \\
\text { Harper PR, } \\
2013\end{array}$ & $\begin{array}{l}\text { Existing Stock: Dentist and } \\
\text { dental therapist numbers } \\
\text { were estimated for } 1 \text { NHS } \\
\text { Administrative Zone: } \\
\text { South Central Strategic } \\
\text { Health Authority (SHA). } \\
\text { Dentist numbers were } \\
\text { available for baseline } \\
\text { (2007) and past trend was } \\
\text { accommodated for future } \\
\text { years (2008 and 2013). } \\
\text { Therapist numbers based } \\
\text { on national dentist to } \\
\text { therapist ratio (1:19). } \\
\text { Flows: Migration, return to } \\
\text { work and attrition were } \\
\text { not identified in the model. } \\
\text { Newly trained: New } \\
\text { dental therapist training } \\
\text { places ( } n=34 \text { ) } \\
\text { accommodated for } \\
\text { projection years } 2008 \text { and } \\
\text { 2013. } \\
\text { Workforce } \\
\text { participation/FTE: NHS } \\
\text { FTE considered for } \\
\text { dentists and therapists; } \\
\text { Final estimates are } \\
\text { presented in workforce } \\
\text { numbers i.e., number of } \\
\text { dentists and therapists. }\end{array}$ & $\begin{array}{l}\text { Information } \\
\text { Centre UK; } \\
\text { NHS South } \\
\text { Central SHA; } \\
\text { Local survey of } \\
\text { skill mix from } \\
\text { Buching- } \\
\text { hamshire and } \\
\text { Milton Keys } \\
\text { Dental } \\
\text { Workforce } \\
\text { Survey }\end{array}$ & $\begin{array}{l}\text { Population: All people at NHS South Central SHA } \\
\text { Demand: Oral health trend, and proportion of } \\
\text { treatment provided by NHS under } 4 \text { bands were } \\
\text { available: } \\
\text { - } \quad \text { Band 1: Examination, diagnosis, preventive } \\
\text { - } \quad \text { Band 2: Band } 1+\text { Routine treatment including } \\
\quad \text { fillings and extractions } \\
\text { - Band 3: Band } 1+\text { complex work such as } \\
\quad \text { dentures, crowns and bridges } \\
\text { - Urgent/Emergency } \\
\text { Proportion of care provided by therapists under } \\
\text { each of these bands estimated. } \\
\text { Three ages groups (0 to } 19 \text { years, } 20-64 \text { years and } \\
\text { 65+ years) were used to estimate future dental } \\
\text { demand. } \\
\text { The model was developed with key parameters that } \\
\text { affect the changes in needs and demand: } \\
\text { demographic changes, oral } \\
\text { health trends, dental attendance and proportion of } \\
\text { treatments attended by each age group. } \\
\text { Workforce requirement: NHS FTE potentially } \\
\text { estimated to arrived at workforce numbers to meet } \\
\text { demand. }\end{array}$ & $\begin{array}{l}\text { The Information Centre } \\
\text { UK; } \\
\text { NHS South Central SHA }\end{array}$ & $\begin{array}{l}\text { Approach: Supply and } \\
\text { Demand models workforce } \\
\text { outputs compared. Linear } \\
\text { programming developed to } \\
\text { obtain optimal makeup of } \\
\text { workforce and project the } \\
\text { future requirements of } \\
\text { workforce supply. The model } \\
\text { took various inputs estimates: } \\
\text { treatments, cost/volume of } \\
\text { activity, staff type or skill mix. } \\
\text { Skill mix: A range of future } \\
\text { scenarios were accounted in } \\
\text { the models, which took into } \\
\text { account use of therapists along } \\
\text { with dentists. }\end{array}$ \\
\hline
\end{tabular}


Table 2. Cont.

\begin{tabular}{|c|c|c|c|c|c|c|}
\hline $\begin{array}{l}\text { Study } \\
\text { No. }\end{array}$ & $\begin{array}{l}\text { Author(s), } \\
\text { Year }\end{array}$ & Supply Model & & Demand I Ne & ds Model & Modelling Technique \\
\hline \multirow[t]{2}{*}{12} & \multirow[t]{2}{*}{$\begin{array}{c}\text { Gallagher JE, } \\
\text { Manickam S } \\
\text { \& Wilson } \\
\text { NHF, } 2015\end{array}$} & \multirow[t]{2}{*}{$\begin{array}{l}\text { Existing stock: Historical data from } \\
\text { registrations/practice of dentists from } 1990 \text { to } 2012 \\
\text { including stratification by Omani and Expatriate } \\
\text { dentists identified. Projects from } 2013 \text { to } 2020 \text { estimated } \\
\text { based on previous years. } \\
\text { Flows: Migrant and Omani trained dentists accounted } \\
\text { for in the estimates based on previous years. Migration } \\
\text { and attrition maintained at constant levels for all years. } \\
\text { Newly trained: Addition of new graduates to } \\
\text { workforce form Oman Dental College maintained } \\
\text { constant }(n=50) \\
\text { Workforce participation/FTE: Number of Oman and } \\
\text { expatriate dentists }\end{array}$} & \multirow[t]{2}{*}{$\begin{array}{l}\text { Ministry of } \\
\text { Health Oman; } \\
\text { World Health } \\
\text { Organization }\end{array}$} & \multirow[t]{2}{*}{$\begin{array}{l}\text { Population: Overall population of } \\
\text { Oman and projections for years } \\
1990 \text { to } 2020 \text { available in the study. } \\
\text { Population growth continues in an } \\
\text { upward trajectory. } 1990 \text { to } 2012 \\
\text { historical data. Projections } 2013 \\
\text { onwards. }\end{array}$} & \multirow[t]{2}{*}{ Ministry of Health, Oman } & $\begin{array}{l}\text { Approach: Dentist density or } \\
\text { Dentist to population ratios } \\
\text { calculated. Ratios-both for } \\
\text { Omani dentists and Expatriate } \\
\text { dentists. } \\
\text { Three projection models were } \\
\text { made for dentist to population } \\
\text { ratios considered appropriate to } \\
\text { meet: } \\
\text { - WHO European } \\
\text { - } \quad \text { Genchmarks }(1: 2000) \\
\text { - GCC Cooperative Council } \\
\text { - Current global benchmarks } \\
\text { (1:3800) }\end{array}$ \\
\hline & & & & & & $\begin{array}{l}\text { Skill mix: Not identified in the } \\
\text { study/approach }\end{array}$ \\
\hline 13 & $\begin{array}{l}\text { Huang CS } \\
\text { et al., } 2013\end{array}$ & $\begin{array}{l}\text { Existing stock: Number of total dentists }(n=11,449) \\
\text { and basic information on each dentist registered in } \\
\text { Taiwan retrieved from the database of health personnel. } \\
\text { Proportion of female dentists were also taken into } \\
\text { account } \\
\text { Flows: Attrition, retirement and migration were taken } \\
\text { into account, and rate determined based on historical } \\
\text { data. } \\
\text { Newly trained: Yearly pass rates of dental licensing } \\
\text { exam for } 2006 \text { to } 2010 \text { accounted for and average } \\
\text { numbers included in the supply model. This pass rate } \\
\text { also took into considerate number of foreign trained } \\
\text { dentists. } \\
\text { Workforce participation/FTE: Survey to dentists } \\
\text { accounts for practice type and work hours, but clinical } \\
\text { hours and FTE usage is unclear in the study. Workforce } \\
\text { participation is represented as number of dentists } \\
\text { available. }\end{array}$ & $\begin{array}{l}\text { Department of } \\
\text { Health database } \\
\text { on health } \\
\text { personnel, } \\
\text { Executive Yuan } \\
\text { (Taipei, Taiwan) } \\
\text { Dentist practice } \\
\text { activity survey }\end{array}$ & $\begin{array}{l}\text { Population: All people in Taiwan. } \\
\text { Both baseline and projections } \\
\text { available from published } \\
\text { government reports. } \\
\text { Demand: A list of factors identified } \\
\text { in the demand model including } \\
\text { population change, increase in } \\
\text { aged people, economic growth, } \\
\text { new technology etc. But unclear on } \\
\text { how they were used. Dentist to } \\
\text { population ratios are presented as } \\
\text { the means of comparing supply } \\
\text { and demand }\end{array}$ & $\begin{array}{l}\text { Official government reports of } \\
\text { Council for Economic } \\
\text { Planning and Development, } \\
\text { Executive Yuan (Taipei, } \\
\text { Taiwan) }\end{array}$ & $\begin{array}{l}\text { Approach: Dentist to population } \\
\text { ratios are estimated across } 2010 \text { to } \\
\text { 2020. Supply and demand } \\
\text { estimates are compared. } \\
\text { Skill mix: Not identified in the } \\
\text { study/approach }\end{array}$ \\
\hline
\end{tabular}


Table 2. Cont.

\begin{tabular}{|c|c|c|c|c|c|c|}
\hline $\begin{array}{l}\text { Study } \\
\text { No. }\end{array}$ & $\begin{array}{l}\text { Author(s), } \\
\text { Year }\end{array}$ & Supply Model & & \multicolumn{2}{|c|}{ Demand I Needs Model } & Modelling Technique \\
\hline 14 & $\begin{array}{c}\text { Ishimaru M } \\
\text { et al., } 2016\end{array}$ & $\begin{array}{l}\text { Existing stock: Number of } \\
\text { dentists in Japan was estimated } \\
\text { via a survey. Dentists } \\
\text { registration number, year of } \\
\text { registration, year of birth, sex, } \\
\text { main working status, speciality } \\
\text { and geographic postcodes of } \\
\text { practice location were available } \\
\text { from longitudinal survey data } \\
\text { (1972 to 2012). Survey data is } \\
\text { collected every } 2 \text { years. } \\
\text { Flows: Retirees were identified } \\
\text { as those who did not report to } \\
\text { the for two consecutive surveys. } \\
\text { Median age of retirees } \\
\text { calculated at } 65 \text { years, and when } \\
\text { dentists reach the retirement age } \\
\text { they were considered as retirees. } \\
\text { Newly trained: New entrants } \\
\text { were identified via the matched } \\
\text { cohort at } 2012 \text { from NSPDP. } \\
\text { Workforce participation/FTE: } \\
\text { Work status is identified as } 6 \\
\text { main categories: ownership of } \\
\text { practice; employed in dental } \\
\text { clinic, hospital practice, } \\
\text { academic work, and not } \\
\text { reported. Workforce } \\
\text { participation was represented } \\
\text { via dentist numbers based on } \\
\text { active registrations and work } \\
\text { status. }\end{array}$ & $\begin{array}{l}\text { National } \\
\text { Survey of } \\
\text { Physicians, } \\
\text { Dentists and } \\
\text { Pharmacists } \\
\text { (NSPDP) for } \\
\text { 1972-2012. }\end{array}$ & $\begin{array}{l}\text { Population: Population numbers for Japan for } \\
\text { years } 1990 \text { to 2012, and } 2014 \text { to } 2042 \text { used. } \\
\text { Both historical estimates and population } \\
\text { projections. }\end{array}$ & $\begin{array}{l}\text { National Institute of } \\
\text { Population and Social } \\
\text { Security Research. }\end{array}$ & $\begin{array}{l}\text { Approach: Dentists to } \\
\text { population ratio (involving } \\
\text { work status, and male/female } \\
\text { dentists differentiators). } \\
\text { Dentists work status across the } \\
\text { six categories were identified } \\
\text { for male and female dentists. } \\
\text { Changes in distribution of } \\
\text { work status accommodated for } \\
\text { selected dentists at } 0.5 \text { and } 10 \\
\text { years after registration for } \\
\text { years } 1982,1992,2002 \text { and } \\
\text { 2012. } \\
\text { Probabilities for change in } \\
\text { dentists work status were } \\
\text { calculate for a wide range of } \\
\text { patterns (78 patterns) for age } \\
\text { and years of experience. } \\
\text { Transition matrix models were } \\
\text { developed using Markov } \\
\text { chains to estimate future } \\
\text { dentists. } \\
\text { Skill mix: Not identified in the } \\
\text { study/approach }\end{array}$ \\
\hline
\end{tabular}


Table 2. Cont.

\begin{tabular}{|c|c|c|c|c|c|c|c|}
\hline Study No. & $\begin{array}{l}\text { Author(s), } \\
\text { Year }\end{array}$ & Supply Model & & \multicolumn{3}{|c|}{ Demand I Needs Model } & Modelling Technique \\
\hline 15 & $\begin{array}{l}\text { Jaiswal AK } \\
\text { et al., } 2014\end{array}$ & $\begin{array}{l}\text { Existing stock: Based on dentists registrations } \\
\text { across various states/territories. Number of } \\
\text { dental institutions in India, undergraduate and } \\
\text { postgraduate student positions obtained from } \\
\text { the Dental Council of India. } \\
\text { Flows: Not identified in the study } \\
\text { Newly trained: Undergraduate placements in } \\
\text { schools/colleges identified, but separately and } \\
\text { not incorporated in the supply model. } \\
\text { Workforce participation/FTE: Number of } \\
\text { dentists used to identify workforce } \\
\text { participation. }\end{array}$ & $\begin{array}{l}\text { Central Bureau of } \\
\text { Health } \\
\text { Intelligence; } \\
\text { Dental Council of } \\
\text { India }\end{array}$ & \multicolumn{3}{|c|}{$\begin{array}{l}\text { Ministry of Health and Family Welfare; } \\
\text { Previous studies via literature }\end{array}$} & $\begin{array}{l}\text { Approach: Dentist to population } \\
\text { ratios were estimated using dentist } \\
\text { registrations and population } \\
\text { numbers, both for India, and } \\
\text { individually for each of the States } \\
\text { of India. This was determined for } \\
\text { one year only (i.e., 2014). } \\
\text { Growth in dental college numbers } \\
\text { were provided from } 1947 \text { to } 2014 \text {. } \\
\text { Trends in increase in number of } \\
\text { registered dentists from } 1994 \text { to } \\
2012 \text { was also provided separately, } \\
\text { but not included as a main } \\
\text { component of the modelling. } \\
\text { Skill mix: Not identified in the } \\
\text { study/approach }\end{array}$ \\
\hline 16 & $\begin{array}{l}\text { Ju X et al., } \\
\quad 2010\end{array}$ & $\begin{array}{l}\text { Existing stock: Oral and maxillo facial } \\
\text { surgeons (OMFS) estimates were available } \\
\text { through from a survey, with information } \\
\text { collected from speciality of practice question } \\
\text { from a survey. OMFS estimates were available } \\
\text { by age, sex and which state/territory they } \\
\text { practised in Australia. } \\
\text { Flows: Retirement, migration, cessation of } \\
\text { practice or death accounted in the model. } \\
\text { Attrition rates calculated based on male } \\
\text { general dental practitioner wastage rates. } \\
\text { Newly trained: Recruitment of OMFS was } \\
\text { determined as the average number of } \\
\text { completions between the years } 2001 \text { and } 2005 . \\
\text { This estimate was validated by the number } \\
\text { trainees currently enrolled in OMFS training } \\
\text { programs in Australia. } \\
\text { Workforce participation/FTE: Participation } \\
\text { was represented by the number of practising } \\
\text { oral and maxillo facial surgeons; work status } \\
\text { was obtained from the survey to determine } \\
\text { practising oral and maxillo facial surgeons. }\end{array}$ & $\begin{array}{l}\text { National Dental } \\
\text { Labour Force } \\
\text { Survey, } 2006 \\
\text { Previous } \\
\text { publication on all } \\
\text { dentists in } \\
\text { Australia for male } \\
\text { general } \\
\text { practitioner } \\
\text { wastage rates; } \\
\text { Source unclear for } \\
\text { overseas entrants } \\
\text { and returned to } \\
\text { practice OMFS. } \\
\text { Australasian } \\
\text { Council of Dental } \\
\text { Schools for } \\
\text { recruitment } \\
\text { vector; }\end{array}$ & \multicolumn{2}{|c|}{$\begin{array}{l}\text { Population: Population data for all } \\
\text { Australians. Age specific information } \\
\text { was included for } 6 \text { age groups. } \\
\text { Demand: Six types of oral and maxillo } \\
\text { facial services provided were identified: } \\
\text { dentoalveolar, trauma, pathology, } \\
\text { orthognathic, reconstructive surgery and } \\
\text { other. Population estimates for people } \\
\text { with oral and maxillo facial conditions } \\
\text { were extrapolated based on service } \\
\text { provision identified from the survey. } \\
\text { Workforce requirement: Estimates on } \\
\text { number of oral and maxillo facial } \\
\text { surgeons required to meet the number of } \\
\text { services estimated were calculated, and } \\
\text { applied under different demand growth } \\
\text { scenarios. It is unclear if FTE was used, or } \\
\text { what is the ratio of surgeons to services } \\
\text { utilised for demand. }\end{array}$} & $\begin{array}{l}\text { Australian Bureau of Statistics } \\
\text { for population data and } \\
\text { projections } \\
\text { Previous published reports on } \\
\text { practice patterns and oral and } \\
\text { maxillo facial services } \\
\text { provided to patients. }\end{array}$ & $\begin{array}{l}\text { Approach: Supply and demand } \\
\text { models were developed separately } \\
\text { and superimposed to identify gap } \\
\text { in OMFS services. Both supply } \\
\text { and demand projections were } \\
\text { estimated from } 2007 \text { to } 2037 . \\
\text { Seven different types of supply } \\
\text { scenarios and five different } \\
\text { demand scenarios were used in } \\
\text { the projection models. } \\
\text { These models were later } \\
\text { reconciled into three broad types: } \\
\text { - Low supply and NO growth } \\
\quad \text { in demand } \\
\text { Medium supply and Half } \\
\text { growth in demand } \\
\text { High supply and Continued } \\
\quad \text { growth in demand. } \\
\text { Skill mix: Not identified in the } \\
\text { study/approach }\end{array}$ \\
\hline
\end{tabular}


Table 2. Cont.

\begin{tabular}{|c|c|c|c|c|c|c|}
\hline Study No. & $\begin{array}{c}\text { Author(s), } \\
\text { Year }\end{array}$ & Supply Model & & Demand I Needs & Model & Modelling Technique \\
\hline 17 & $\begin{array}{l}\text { Mills RW, } \\
2020\end{array}$ & $\begin{array}{l}\text { Existing stock: Number of dental specialists } \\
\text { across all specialities in the UK were obtained } \\
\text { from registrations data for } 20 \text { years (1999 to } \\
\text { 2019). Postcode of practice location of these } \\
\text { specialists were also obtained from the GDC } \\
\text { registrations website information. }\end{array}$ & $\begin{array}{l}\text { General Dental } \\
\text { Council Specialist } \\
\text { Registrations }\end{array}$ & NA & NA & $\begin{array}{l}\text { Approach: Supply data of dental } \\
\text { specialists were matched by } \\
\text { postcode of practice location. } \\
\text { Differences in practice location of } \\
\text { specialities and lack of specialists } \\
\text { in certain postcode areas were } \\
\text { identified. Geographic } \\
\text { information system approaches } \\
\text { were used. } \\
\text { Skill mix: Not identified in the } \\
\text { study/approach }\end{array}$ \\
\hline 18 & $\begin{array}{c}\text { Saman DM, } \\
\text { Arevalo O \& } \\
\text { Johnson AO, } \\
2010\end{array}$ & $\begin{array}{l}\text { Existing stock: Dentist numbers were available } \\
\text { from registrations, and location of practice } \\
\text { mapped. } \\
\text { Flows: Incoming and retiring dentists } \\
\text { identified (change in results section). } \\
\text { Newly trained: Not identified in the } \\
\text { study/approach. } \\
\text { Workforce participation/FTE: Number of } \\
\text { dentists used for workforce participation. }\end{array}$ & $\begin{array}{l}\text { Kentucky Board } \\
\text { of Dentistry }\end{array}$ & Population: All population of Kentucky. & Kentucky State Data Centre & $\begin{array}{l}\text { Approach: Dentist to population } \\
\text { ratios were projected for each } \\
\text { geographic area in Kentucky from } \\
2007 \text { up to 2016. The simulation } \\
\text { model includes aspects of } \\
\text { geospatial modelling to identify } \\
\text { and map the dentist to population } \\
\text { ratios. } \\
\text { Skill mix: Not identified in the } \\
\text { study/approach }\end{array}$ \\
\hline 19 & $\begin{array}{c}\text { Shaw JL et al., } \\
2017\end{array}$ & $\begin{array}{l}\text { Existing stock: Number of dentists, specialists } \\
\text { and allied dental practitioners available in the } \\
\text { human resources management system. } \\
\text { Flows: Not identified in the approach/study } \\
\text { Newly trained: Not identified in the } \\
\text { approach/study } \\
\text { Workforce participation/FTE: FTE was } \\
\text { calculated based on standard hours worked by } \\
\text { a full time dentist ( } n=1229.5 \mathrm{~h}) \text {. The number } \\
\text { of clinical hours were adjusted to reflect } \\
\text { clinical FTE, and variations in clinical } \\
\text { provision adjusted across army ranks. }\end{array}$ & $\begin{array}{l}\text { Human Resource } \\
\text { Management } \\
\text { System of } \\
\text { Canadian Armed } \\
\text { Forces (CAF) } \\
\text { Canadian Forces } \\
\text { Dental Services } \\
\text { (CFDS) RESTORE } \\
\text { \& CFDS Position } \\
\text { Charter (Policy } \\
\text { documents) }\end{array}$ & $\begin{array}{l}\text { Population: All people living in } \\
\text { catchment areas served by the CAF } \\
\text { clinics. } \\
\text { Demand: Oral health status information } \\
\text { of CAF personnel in catchment areas } \\
\text { surveyed, along with treatment plan data. } \\
\text { Workforce requirement: FTE requirement } \\
\text { were estimated based on hours required } \\
\text { to meet the demand. }\end{array}$ & $\begin{array}{l}\text { Dental Information System } \\
\text { (DentIS) } \\
\text { Oral health surveillance data } \\
\text { from a cross sectional sample } \\
\text { of CAF personnel }\end{array}$ & $\begin{array}{l}\text { Approach: FTE dentist } \\
\text { requirements under both } \\
\text { workforce to population ratio, and } \\
\text { demand models were estimated. } \\
\text { This calculation was extended to } \\
\text { all geographic areas served under } \\
\text { the CAF catchments. } \\
\text { Level of FTE dentists agreement } \\
\text { between the dentist to population } \\
\text { model and demand model were } \\
\text { assessed using Intraclass } \\
\text { Correlation Coefficient and } \\
\text { Bland-Altman plots. } \\
\text { Skill mix: Though Skill mix in } \\
\text { CAF is identified, only general } \\
\text { dentists FTE seen in models } \\
\text { presented. }\end{array}$ \\
\hline
\end{tabular}


Table 2. Cont.

\begin{tabular}{|c|c|c|c|c|c|c|}
\hline $\begin{array}{l}\text { Study } \\
\text { No. }\end{array}$ & $\begin{array}{c}\text { Author(s), } \\
\text { Year }\end{array}$ & & Supply Model & Demand I Needs Model & & Modelling Technique \\
\hline 20 & $\begin{array}{c}\text { Sun X et al., } \\
2017\end{array}$ & NA & NA & $\begin{array}{l}\text { Population: Children; } 12 \text { year olds from } 31 \text { provinces of } \\
\text { Mainland China, except Tibet. } \\
\text { Needs: A representative sample of } n=23,508 \text { children } \\
\text { (12 years) clinically examined, and questionnaire } \\
\text { survey for } n=12,392 \text {. Oral health status measured } \\
\text { included dental caries experience and periodontal } \\
\text { assessment. Oral health behaviours assessed via } \\
\text { questionnaire. Four risk groups identified based on } \\
\text { caries and behavioural assessment: } \\
\text { - High risk } \\
\text { - Low risk } \\
\text { - Relatively high risk } \\
\text { - Relatively low risk } \\
\text { Workforce requirement: Risk based intervention } \\
\text { models (maximum and minimum intervention) were } \\
\text { developed and frequency of required dental visits } \\
\text { estimated based on the four risk groups. Timings for } \\
\text { care for each child were determined from panel of } \\
\text { experts, and were aggregated to represent each child } \\
\text { based on the risk level. Total timings for all } 12 \text { year olds } \\
\text { in China was estimated using a population weighting } \\
\text { approach. These timings for treatment were converted } \\
\text { to workforce requirement based on average working } \\
\text { hours per week (37.85 her dental professional) to } \\
\text { arrive at dental workforce numbers. } \\
\text { Percentage of care provided for } 12 \text { year olds estimated } \\
\text { at } 1.27 \text { percent. Similar workforce requirement was } \\
\text { made for full population in China, based on } \\
12 \text { year olds. }\end{array}$ & $\begin{array}{l}\text { 3rd National Oral Health } \\
\text { Survey } \\
\text { Panel of nine experts from } \\
\text { Peking University for data } \\
\text { on timings for dental } \\
\text { professionals } \\
\text { Previous study (No 22) } \\
\text { Wanyonyi et al., } 2015 \text { for } \\
\text { data on percentage of care } \\
\text { for } 12 \text { year olds. }\end{array}$ & $\begin{array}{l}\text { Approach: Dental workforce } \\
\text { requirements estimated based } \\
\text { on a needs informed approach } \\
\text { from a national population } \\
\text { survey of } 12 \text { year olds in } \\
\text { China. Percentage of time } \\
\text { spent on } 12 \text { year olds was } \\
\text { estimated, and workforce } \\
\text { requirements both for } 12 \text { years } \\
\text { olds and for all population in } \\
\text { China was calculated. } \\
\text { Skill mix: Not identified in the } \\
\text { study/approach }\end{array}$ \\
\hline
\end{tabular}


Table 2. Cont.

\begin{tabular}{|c|c|c|c|c|c|c|}
\hline Study No. & $\begin{array}{l}\text { Author(s), } \\
\text { Year }\end{array}$ & Supply Model & & Demand I Needs I & Model & Modelling Technique \\
\hline 21 & $\begin{array}{l}\text { Surdu S et al., } \\
2016\end{array}$ & $\begin{array}{l}\text { Existing stock: Active paediatric } \\
\text { dentists in the United States } \\
\text { estimated using the membership } \\
\text { data, and a } 6 \% \text { adjustment for non } \\
\text { members. Overall } n=6530 \\
\text { paediatric dentists. } \\
\text { Flows: Intended retirement age } \\
\text { collected via online survey. All } \\
\text { dentists were assumed to retire at } \\
75 \text { years. Age dependent attrition } \\
\text { rates calculated either based on US } \\
\text { mortality rates (for less than } 50 \\
\text { years of age) or using survey } \\
\text { responses. Annual cross state } \\
\text { migration estimated via a logistic } \\
\text { regression model using survey } \\
\text { data on all dentists younger than } \\
\text { 50 years. Unclear if overseas } \\
\text { migration, and long term } \\
\text { migration has been accounted for. } \\
\text { Newly trained: Number of new } \\
\text { graduates entering the paediatric } \\
\text { dental workforce assumed based } \\
\text { on previous publication/data }(n= \\
448 ; 63.5 \% \text { female). Age } \\
\text { distribution of new graduates } \\
\text { calculated based on new members } \\
\text { data. } \\
\text { Workforce participation/FTE: } \\
\text { Information on patient care hours } \\
\text { per week collected from an online } \\
\text { survey of all paediatric dentists, } \\
\text { who were association members } \\
\text { with a US postal address. } \\
\text { Ordinary least squares regression } \\
\text { analysis used to model total } \\
\text { weekly patient hours across } \\
\text { various practice setting. FTE } \\
\text { defined at } 32.6 \text { h per week in } \\
\text { patient care activities }\end{array}$ & $\begin{array}{l}\text { American } \\
\text { Association for } \\
\text { Paediatric } \\
\text { dentists } \\
\text { membership data; } \\
\text { Online survey of } \\
\text { paediatric } \\
\text { dentistry practice } \\
\text { in 2016; } \\
\text { Previous } \\
\text { publication from } \\
\text { American Dental } \\
\text { Association } \\
\text { (ADA), Health } \\
\text { Policy Institute; }\end{array}$ & $\begin{array}{l}\text { Population: Representative sample of child } \\
\text { population for each state collected from US } \\
\text { Census and Behavioural Risk Factor } \\
\text { surveys ( } n=656,400 \text { ). This sample was } \\
\text { weighted to represent the population in } \\
\text { each state in the US (at national level } \\
\text { summed up to } 73.6 \text { million children under } \\
17 \text { years of age). The population data } \\
\text { contained information on age, sex, race, } \\
\text { ethnicity, income, medical insurance and } \\
\text { residence. Population projections } 2015 \text { to } \\
2030 \text { were made represent these sample } \\
\text { characteristics, by scaling up the weights } \\
\text { for the individual people in the sample. } \\
\text { Demand: Patterns of care from MEPS } \\
\text { survey were modelled to understand } \\
\text { annual encounters to dental visits, } \\
\text { considering age, sex, ethnicity, insurance, } \\
\text { and geographic area as explanatory } \\
\text { variables. Poisson regression was used to } \\
\text { model patterns of annual care. All visits } \\
\text { excluding prophylaxis and visits related to } \\
\text { orthodontic procedures considered. } \\
\text { Workforce requirement: Number of } \\
\text { paediatric dentists required to meet supply } \\
\text { were estimated to meet the demand, using } \\
\text { various scenarios. }\end{array}$ & $\begin{array}{l}\text { American Community Survey; } \\
\text { Centre for Disease Control } \\
\text { and Prevention } 2014 \text { and } 2015 \\
\text { Behavioural Risk Factor } \\
\text { Surveillance Data; } \\
\text { US Mortality Register; } \\
\text { Medical Expenditure Panel } \\
\text { Survey (MEPS) } 2010 \text { to } 2014 \\
\text { data. }\end{array}$ & $\begin{array}{l}\text { Approach: Supply model based on a } \\
\text { microsimulation approach to model future } \\
\text { supply under a range of assumptions. } \\
\text { Demand model for services based on } \\
\text { patterns of care and visits using a range of } \\
\text { population and oral health data. } \\
\text { Sensitivity analysis was used for supply } \\
\text { estimates; Weighting for both supply and } \\
\text { demand estimates; least squares regression } \\
\text { to model total weekly patient care hours; } \\
\text { logistic regression to model interstate } \\
\text { migration; Poisson regression to model } \\
\text { annual care; Scenarios to model derived } \\
\text { demand for dentists / paediatric dentists. } \\
\text { Derived demand for dentists modelled using } \\
\text { scenarios based on how workforce } \\
\text { requirement will vary based on services and } \\
\text { removal of barriers to access. } \\
\text { Scenario 1: Continuation of care } \\
\text { Scenario 2: Hypothetical-pediatric dentists } \\
\text { provide care for all children under } 4 \text { years; } \\
\text { 80\% care for childre 5-12 years, and } 20 \% \text { care } \\
\text { for children } 13 \text { to } 17 \text { years; } \\
\text { - Scenario 3: Hypothetical; All children } \\
\quad \text { will have access to care and access } \\
\text { barriers removed (approximates a } \\
\text { needs-based scenario) } \\
\text { Scenario } 4 \text { : Builds on Scenario } 1 \text { but } \\
\text { including FTE estimates for general } \\
\text { and paediatric dentists } \\
\text { Scenario 5: Builds on Scenario } 3 \text { but } \\
\text { models FTE dentists. } \\
\text { Kill mix: General and paediatric dentists } \\
\text { modelled, but other skill mix considerations } \\
\text { not identified. }\end{array}$ \\
\hline
\end{tabular}


Table 2. Cont.

\begin{tabular}{|c|c|c|c|c|c|c|}
\hline $\begin{array}{l}\text { Study } \\
\text { No. }\end{array}$ & $\begin{array}{c}\text { Author(s), } \\
\text { Year }\end{array}$ & Supply Model & & Demand I Needs Model & & Modelling Technique \\
\hline 22 & $\begin{array}{l}\text { Wanyonyi } \\
\text { KL et al., } \\
2015\end{array}$ & $\begin{array}{l}\text { Dentists and mid level providers } \\
\text { (dental therapists) are identified } \\
\text { as components of the overall } \\
\text { model presented, but not } \\
\text { accounted in the analysis or } \\
\text { study results which focusses on } \\
\text { alternative scenarios based on } \\
\text { workforce requirements (based } \\
\text { on demand but not compared } \\
\text { with supply) }\end{array}$ & $\begin{array}{l}\text { General Dental } \\
\text { Council }\end{array}$ & $\begin{array}{l}\text { Population: All population in England (both } \\
\text { adults and children), who avail public dental } \\
\text { care } \\
\text { Demand: NHS dental services and treatment } \\
\text { provided at a single site at South England were } \\
\text { used to estimate age specific treatment rates } \\
\text { across all NHS services for England. Timings for } \\
\text { treatments were accounted using British Dental } \\
\text { Association timings, and verified with expert } \\
\text { panel. Total demand was expressed in age } \\
\text { specific clinical hours. } \\
\text { Workforce requirement: Workforce estimates } \\
\text { were calculated based on the basis that dentists } \\
\text { spend 0.4 FTE and hygienists/therapists spend } \\
0.3 \text { FTE of clinical hours for NHS work. Overall } \\
\text { number of dentists and therapists required was } \\
\text { expressed as alternative scenarios accounting } \\
\text { for skill mix, and costs. }\end{array}$ & $\begin{array}{l}\text { NHS Electronic Health } \\
\text { Records Treatment } \\
\text { data (single site at } \\
\text { South England) } \\
\text { British Dental } \\
\text { Association timings for } \\
\text { services } \\
\text { Expert panel to } \\
\text { validate treatment } \\
\text { timings } \\
\text { Salaries from National } \\
\text { Career Service Advice }\end{array}$ & $\begin{array}{l}\text { Approach: Treatment provision or } \\
\text { utilisation data used in } \\
\text { determining age specific treatment } \\
\text { rates and timings of service. The } \\
\text { later used to account for } \\
\text { dentist/therapist FTE and costs } \\
\text { based on skill mix alternative } \\
\text { scenarios. } \\
\text { Skill mix: Four NHS activity } \\
\text { scenarios were used that } \\
\text { accounted for delegation of tasks } \\
\text { to dental hygienists/therapists: } \\
\text { - } \quad \text { Not skill mix } \\
-\quad \text { Minimal direct access } \\
\text { - More prevention } \\
\text { - Maximum delegation }\end{array}$ \\
\hline 23 & $\begin{array}{l}\text { Zhang Y } \\
\text { et al., } 2015\end{array}$ & $\begin{array}{l}\text { Existing stock: Survey of all } \\
\text { practices in a single Province in } \\
\text { China, including } n=2155 \text { dental } \\
\text { practices and } n=8611 \text { oral } \\
\text { health personnel (including } \\
\text { dentists, nurses and technicians). } \\
\text { Education, professional level, } \\
\text { area of practice captured in the } \\
\text { survey. } \\
\text { Flows: Not identified in the } \\
\text { study. } \\
\text { Newly trained: Not identified in } \\
\text { the study. } \\
\text { Workforce participation/FTE: } \\
\text { Hours worked collected in the } \\
\text { survey, but its application } \\
\text { towards the supply model is } \\
\text { unclear. }\end{array}$ & $\begin{array}{l}\text { Questionnaire } \\
\text { survey sent to } \\
\text { all dental } \\
\text { facilities by } \\
\text { Sanitation } \\
\text { Bureau and } \\
\text { Health } \\
\text { Supervision } \\
\text { station }\end{array}$ & $\begin{array}{l}\text { Population: All population from a single } \\
\text { Province (Liaoning) in China }\end{array}$ & Survey; Unclear & $\begin{array}{l}\text { Approach: Number of dentists per } \\
\text { population for the Province } \\
\text { estimated (at current levels). } \\
\text { Population projection for } 2020 \text { and } \\
\text { workforce requirements to meet } \\
\text { the population at } 2020 \text { was } \\
\text { determined by using WHO } \\
\text { recommended ratios. The gap in } \\
\text { dental workforce for future } \\
\text { identified, accounting a list of } \\
\text { scenarios based on needs, } \\
\text { amounts of time worked by } \\
\text { dentists and dentist to population } \\
\text { ratios } \\
\text { Skill mix: Not identified in the } \\
\text { study/approach }\end{array}$ \\
\hline
\end{tabular}


Surdu et al. [45] documented an elaborate use of national dental association registrations data for determining supply estimates of pediatric dentists, in addition to survey and workforce publications from government sources. Nine studies have included flow estimates within their supply models, through the inclusion of migration, retirement, absence, return to work and deaths $[23,28,31,34-36,38,39,45]$. Ten studies have included newly trained dentists in the supply model $[23,25,28,30,31,34-36,38,39,45]$, mostly through information available from dental school completions. Brailsford \& De Silva [35] also incorporated a student survey to understand student motivations and career expectations. A few studies have also accommodated government regulations and potential for newly created dentists/hygienist places in their supply estimates [34,38,39].

Studies have represented overall workforce participation either through dental personnel numbers alone $(n=5)[25,29,30,34,44]$ or accounting for clinical or part time hours worked and determining full time equivalent dentists $(n=7)[24,31,35,38,39,42,45]$. Ju et al. [23] and Ishimaru et al. [28] have used work status questions from surveys in determining workforce participation.

\subsubsection{Demand Models, Population Only Estimates and Data Sources}

Demand models, represented as a needs-based demand weighted or utilization/ demand model were presented in nine studies [23,35,38-40,42,43,45]. At the basic level estimates were presented as only population numbers in eight studies [25,27-30,34,36,44]. Population estimates were sourced from national or state-based census sources, government departments, or a combination of both. Seven studies [23,24,35,38-40,45] estimated the expressed demand through available data on oral health status, and converted the demand to workforce requirements as minutes, dentists or FTE dentists. Brailsford De Silva [35] used FDI/WHO method in estimating services needed per person-based on people who actively express the need for care from a population survey. Three studies in the UK (Gallagher [38,39]; Wanyoyi, [40]) have used NHS treatment data to arrive at a very detailed estimates of demand and workforce requirement. A simple estimation of demand was reported in Eklund and Balit [43] — the proportion of dental visits people make in a year (determined form a previous publication) in estimating workforce requirements.

\subsubsection{Needs Models and Data Sources}

The review identified four studies [26,31-33] that have predominantly used a needs model in determining workforce requirements. All four studies used a population survey to determine oral health status and treatment needs. Three studies were limited in survey design or sample size or research question: Sun et al. [26] surveyed only 12-year-olds in China, and Ab-Murat et al. [32,33] surveyed 30-54-year-old university employees at a single site (public university) in Malaysia. Ab-Murat et al. [32,33] also focused on specific aspects covering periodontal and prosthodontic treatment needs, which were measured through two approaches: a normative approach and socio dental approach. Face-to-face questionnaires were also used to determine oral health impacts and behaviours. Both $\mathrm{Ab}$ Murat et al. [32,33] and Sun et al. [26] used panel interviews to determine treatment timings, helping in the estimation of workforce requirement. Sun et al. [26] further expanded the needs aspect (determined for 12-year olds) to whole population in China by utilizing care provision ratios, adopted from a previous study. In contrast, Ahern et al. (2019) [31] used a more comprehensive oral health survey dataset that covered all adults (15+ years old) in Ireland. The population survey included questions on oral health status, behaviours, impacts and visiting patterns to determine service timings and workforce requirements in FTE dentists.

\subsubsection{Skill Mix Considerations}

The use of skill mix in modelling that take into account the contribution or influence of different workforce groups towards supply, demand and/or need models has been limited. Only seven studies accounted for skill mix variations $[32,33,38-40,42,45]$. The common 
application of skill mix was the use of allied dental teams (dental therapists, hygienists, denturists) along with dentists $[32,33,38-40,42]$. Surdu et al. [45] have applied specialist pediatric dentists along with general dentists in skill mix models for planning pediatric dental workforce. Studies that used skill mix accounted for changes in the provision of services by the extended dental team and how their participation effectively altered the future workforce requirements for oral health care. None of the studies examined the provision of oral health care outside the main oral health workforce groups i.e., accounting for possible care provision by medical, nursing, pharmacy or broader allied health workforce teams. While a few studies have discussed the concept of skill mix within dental teams, they haven't included it within the modelling approaches.

Almost all the models being presented were deterministic; only one study included a stochastic element in their modelling approach [38]. A number of studies identified limitations in relation to data sources, either data being unavailable or on the quality of planning data. Other limitations highlighted were being single site studies, small sample size (see Supplementary Table S3).

\section{Discussion}

The review examined oral health workforce planning models within the published scientific literature over the last 10 years. Many studies were from high-income countries; no studies were identified from low-income countries and the WHO African region. Calculating workforce to population ratios were the most common modelling approach, followed by needs-based demand weighted approaches. Needs-based approaches had limitations in the population being studied and/or the nature of oral health need assessments being undertaken. Lack of quality data for the modelling exercise is omnipresent in all sources of supply, demand and needs. Very few studies have made use of skill mix considerations in their models. Studies have not accounted for uncertainty of outcomes, or randomness in their modelling exercises, and were mostly deterministic in nature.

Workforce to population ratios, though commonly used in oral health workforce planning studies, represent a crude ratio and bring several shortcomings to the planning process. First, this ratio is based on assumptions of homogeneity across the numerator (i.e., all dental personnel are active and equally productive and will remain so) and that the denominator (i.e., all populations) will have similar oral health needs and will remain constant) [6,12]. This ratio does less justice to address differences in dentist practice activity or productivity (across age, sex, levels of experience, area of practice) or varying levels of oral disease prevalence, dental care utilisation or demographic, socio-economic differences of across population groups. Second, maldistribution of health personnel across different geographic areas, practice types (public or private) or facilities (hospitals, clinics) cannot be adequately represented using a single workforce to population ratio [5]. While it is possible to offer some comparisons using workforce to population ratios at global, region, country, state/area, facility levels, its inability to account for the intrinsic differences in dentist and disease characteristics would still prevail. Third, the ratio does not help us in understanding progress made in achieving wider health system objectives and performance benchmarks in regard to accessibility, equity, quality and efficiency, [6] particularly as the most basic aspect of access 'coverage' within countries can differ, particularly between urban and rural areas (ref)Nevertheless, the workforce to population ratio approach is less demanding in terms of data and it brings simplicity in terms of providing a snapshot estimate to health planners [4,5,46]. Our review identified studies from Kuwait [29], Trinidad and Tobago [37], Chile [25], Oman [34], Taiwan [36], India [30], China [26], UK (dental specialists) [41], and Kentucky (USA) [44] using a workforce to population ratio approach. It should be noted that all these studies also identified limitations in data sources or non-availability of quality data and they have resorted to using workforce to population ratio as a means of commencing the oral health workforce planning process [47].

Demand based planning approaches primarily make use of health service utilisation data. Our review has identified studies that use both dentist surveys [43] and administrative 
data such as electronic health records (EHR) [40] for extracting oral health service utilisation data. Traditionally, survey-based methods have been popular in understanding practice activity of oral health personnel, and the nature and type of services they offer to patients. For example, in Australia, dentist practice activity surveys have been the cornerstone of oral health workforce policy and planning since early $1980^{\prime}$ s [48-51]. In recent years, however, the adoption and use of computerised systems and use of EHRs in dental practices and hospitals are becoming more common in many counties [52]. EHRs provide a viable, cost efficient and timely alternative to understand dental service utilisation data, against surveys that are more time consuming and resource intensive [53,54]. However, the use of EHRs is still in its infancy in terms of data quality and consistency in systems across public and private sectors [55-57]. As a large proportion of dentists practice in the private sector [7], it becomes important to find avenues to improve consistency as well as building data repositories for research and planning purposes. The International Association for Dental Research (the peak global dental research body), and its Network for Practice Based Research [58] has raised the importance of partnerships across private and public dental sector and Universities to improve quality, consistency and use of oral health service data collected in dental clinics or hospitals for research purposes.

Needs based approaches are more reflective of the underlying oral health needs of population. Such models take into account oral health conditions such as caries levels, periodontal status or missing teeth [26,31-33]. Data for needs in selected studies in the review are from population oral health surveys. However, not all studies were comprehensive, and were limited in the type of population group being surveyed or type of needs being assessed, or oral health status questions being studied.

The use of skill mix is a vital component in health workforce models, as it helps to accommodate task sharing and team work both across members of the dental team and wider medical, nursing and allied health teams. Prior planning theories and methods have to failed to incorporate skill-mix in planning designs [59]. The use of skill mix is an important factor when undergoing oral health workforce planning as it helps to determine the future framework of the oral health team in terms of number, size and consequently patient base [38]. In order to predict the future of the oral health workforce, it is important to appreciate the changes within society in terms of comparing and contrasting oral health need and demands, whilst balancing this against the supply of the dental workforce [60]. Vertical integration of the oral health workforce with other health professionals is also vital moving in the future, as in a post COVID era its logical to argue for greater collaboration with all members of the medical, dental and social teams so as to meet the growing needs and demands of the population [7]. Future research in oral health workforce planning needs to accommodate both horizontal and vertical integration within their planning exercises. A major issue for concern is planning the future dental speciality workforce. As gatekeepers of the dental profession, dental specialists are vital towards setting quality benchmarks, identifying divers for innovation and change. Planning exercises will need to extend to involve dental specialists along with general dentists and other members of the dental team in order to best serve the needs of the population.

The study identified lack of consistency and quality of workforce data arising from a wide variety of data sources. Supply data sources have particularly problematic due to the number of sources required to identify the stock, flows and newly trained. Our prior research has identified a range of inconsistencies across countries in these supply data sources and necessity for advocacy and solutions in improving registration and migration data on dental professionals [8].

\section{Limitations}

This rapid review included only published scientific research articles between 2010 to 2020. We limited our focus only on the past decade, as several advocacy and major progress on health workforce planning by global, regional and national organisations were prevalent during this period. Health workforce planning could also be conducted as an 
'in-house' exercise by planning organisations which is more prevalent in grey literature. Our decision to include only published peer reviewed articles was conscious, mainly due to the rapid review method adopted [17,18], but also able to understand how well oral health workforce planning is represented in our scientific literature. One possible limitation is the fact that the senior author of this review is also active in workforce modelling and has authored several of the publications; however, we took account of this by having a wider research team work on the data extraction and analysis, recognising the importance also of having an expert in the field involved. We also identify a recent review published by a different group of colleagues on a similar topic [61]. Whilst our study differs in terms of review question, methods, and framework used in synthesis, the findings together make a major contribution to this important but relatively unexplored field of oral health workforce planning. The purpose of our review was to distinctly focus on data sources, techniques and skill mix considerations. Our method of synthesis was comprehensive to the above three parameters.

\section{Conclusions}

Planning for the future oral health workforce is heavily reliant on quality data being available for supply, demand and needs models. Studies have presented with a lack of uniformity and accepted standards in oral health workforce modelling approaches and reporting. Integrated methodologies that expand the skill mix considerations and introduce randomness and system dynamics to account for uncertainty are essential for future planning exercises.

Supplementary Materials: The following are available online at https:/ /www.mdpi.com/1660-460 1/18/6/2891/s1, Supplementary Table S1: Search Strategy for the Rapid Review; Supplementary Table S2: Limitations mentioned in selected studies. Supplementary Table S3: List of selected studies for Rapid Review with full citation. Supplementary Table S4: PubMed Search with MeSH terms.

Author Contributions: All authors were equally involved in the design, development and conduct of the rapid review. M.B. wrote the first original draft of the manuscript, and revised the manuscript based on feedback from all authors. S.G. and A.H. conducted the search and identified the first list of articles. M.B., A.H., S.G., \& A.A. were involved in scanning, identification and data extraction. J.G., provided oversight and supervision. All authors have read and agreed to the published version of the manuscript.

Funding: M.B. is supported by an NHMRC Sidney Sax Research Fellowship (GNT: 1121576). S.G. is supported by the Portsmouth Global PhD Scholarship (2019-2022). The contents are solely the responsibility of the administering institution and the authors and do not reflect the views of funding bodies.

Institutional Review Board Statement: Not applicable.

Informed Consent Statement: Not applicable.

Data Availability Statement: All data presented in the study are available in the tables and figures included in this paper.

Conflicts of Interest: J.G. is a co-author on a few of the published papers in this review.

\section{References}

1. World Health Organization. Framing the Health Workforce Agenda for the Sustainable Development Goals: Biennium Report 2016-2017-WHO Health Workforce. Available online: http:/ /www.who.int/hrh/BienniumReportRevised2017.pdf?ua=1 (accessed on 30 December 2020).

2. Campbell, J.; Buchan, J.; Cometto, G.; David, B.; Dussault, G.; Fogstad, H.; Fronteira, I.; Lozano, R.; Nyonator, F.; Pablos-Méndez, A.; et al. Human resources for health and universal health coverage: Fostering equity and effective coverage. Bull. World Health Organ. 2013, 91, 853-863. [CrossRef]

3. Campbell, J.; Dussault, G.; Buchan, J.; Pozo-Martin, F.; Guerra Arias, M.; Leone, C.; Siyam, A.; Cometto, G.A. A Universal Truth: No Health without a Workforce; World Health Organization: Geneva, Switzerland, 2013.

4. Hall, T.L.; Mejia, A. Health Manpower Planning: Principles, Methods and Issues; World Health Organisation: Geneva, Switzerland, 2010; pp. 1-146. 
5. Ono, T.; Lafortune, G.; Schoenstein, M. Health workforce planning in OECD countries: A review of 26 projection models from 18 countries. OECD Health Work. Pap. 2013, 62. [CrossRef]

6. $\quad$ Dreesch, N.; Dolea, C.; Dal Poz, M.R.; Goubarev, A.; Adams, O.; Aregawi, M.; Bergstrom, K.; Fogstad, H.; Sheratt, D.; Linkins, J.; et al. An approach to estimating human resource requirements to achieve the Millennium Development Goals. Health Policy Plan. 2005, 20, 267-276. [CrossRef]

7. Balasubramanian, M.; Brennan, D.S.; Short, S.D.; Gallagher, J.E. A strife of interests: A qualitative study on the challenges facing oral health workforce policy and planning. Health Policy 2019, 123, 1068-1075. [CrossRef] [PubMed]

8. Balasubramanian, M.; Davda, L.; Short, S.D.; Gallagher, J.E. Moving from advocacy to activism? The fourth WHO global forum on human resources for health and implications for dentistry. Br. Dent. J. 2018, 225, 119-122. [CrossRef] [PubMed]

9. Gallagher, J.E.; Wilson, N.H.F. The future dental workforce? Br. Dent. J. 2009, 206, 195-199. [CrossRef]

10. FDI Word Dental Federation. Optimal Oral Health through Inter-Professional Education and Collaborative Practice. Geneva. 2015. Available online: https:/ / www.fdiworlddental.org/sites/default/files/media/news/collaborative-practice_digital.pdf (accessed on 23 February 2018).

11. Balasubramanian, M.; Teusner, D.; Brennan, D. Dental specialists in Australia. Aust. Dent. J. 2010, 55, 96-100.

12. World Health Organization. Models and tools for health workforce planning and projections. Human Resources for Health Observer - Issue Number 3. Available online: https://www.who.int/hrh/resources/observer3/en/ (accessed on 30 December 2020).

13. DeFriese, G.H.; Barker, B.D. Assessing Dental Manpower Requirements: Alternative Approaches for State and Local Planning; Ballinger Publishing Company: Cambridge, MA, USA; Harper \& Row Publishers Inc.: New York, NY, USA, $1982 ; 15$ p.

14. World Health Organization. Dublin Declaration on Human Resources for Health [Internet]. Fourth Global Forum on Human Resources for Health. Dublin, Ireland. Available online: http://www.who.int/hrh/events/Dublin_Declarationon-HumanResources-for-Health.pdf?ua=1\%0Ahttp:/ / www.who.int/hrh/news / 2017/action-to-avert-an18-million-healthworker-shortfall/en/ (accessed on 30 December 2020).

15. Birch, S.; Ahern, S.; Brocklehurst, P.; Chikte, U.; Gallagher, J.; Listl, S.; Lalloo, R.; O’Malley, L.; Rigby, J.; Tickle, M.; et al. Planning the oral health workforce: Time for innovation. Community Dent. Oral Epidemiol. 2021, 49, 17-22. [CrossRef]

16. World Health Organization. Global Strategy on Human Resources for Health: Workforce; WHO: Geneva, Switzerland, 2016.

17. Thomas, J.; Newman, M.; Oliver, S. Rapid evidence assessments of research to inform social policy: Taking stock and moving forward. Évid. Policy J. Res. Debate Pract. 2013, 9, 5-27. [CrossRef]

18. Khangura, S.; Konnyu, K.; Cushman, R.; Grimshaw, J.; Moher, D. Evidence summaries: The evolution of a rapid review approach. Syst. Rev. 2012, 1, 10. [CrossRef] [PubMed]

19. Tricco, A.C.; Antony, J.; Zarin, W.; Strifler, L.; Ghassemi, M.; Ivory, J.; Perrier, L.; Hutton, B.; Moher, D.; Straus, S.E. A scoping review of rapid review methods. BMC Med. 2015, 13, 1-15. [CrossRef]

20. Langlois, E.V.; Straus, S.E.; Antony, J.; King, V.J.; Tricco, A.C. Using rapid reviews to strengthen health policy and systems and progress towards universal health coverage. BMJ Glob. Health 2019, 4, 1-4. [CrossRef]

21. Haby, M.M.; Chapman, E.; Clark, R.; Barreto, J.; Reveiz, L.; Lavis, J.N. What are the best methodologies for rapid reviews of the research evidence for evidence-informed decision making in health policy and practice: A rapid review. Health Res. Policy Syst. 2016, 14, 1-12. [CrossRef] [PubMed]

22. Ouzzani, M.; Hammady, H.; Fedorowicz, Z.; Elmagarmid, A. Rayyan—a web and mobile app for systematic reviews. Syst. Rev. 2016, 5, 1-10. [CrossRef] [PubMed]

23. Ju, X.; Spencer, A.; Brennan, D. ARCPOH (Australian Research Centre for Population Oral Health) The University of Adelaide. Supply and demand for oral and maxillofacial surgeons and services in Australia. Aust. Dent. J. 2010, 55, 346.

24. Shaw, J.L.; Farmer, J.W.; Coyte, P.C.; Lawrence, H.P. Comparing human resource planning models in dentistry: A case study using Canadian Armed Forces dental clinics. Community Dent. Oral Epidemiol. 2017, 45, 209-215. [CrossRef]

25. Cartes-Velasquez, R.A. Exponential growth of dental schools in Chile: Effects on academic, economic and workforce issues. Braz. Oral Res. 2013, 27, 471-477. [CrossRef]

26. Sun, X.; Bernabé, E.; Liu, X.; Zheng, S.; Gallagher, J.E. Meeting the oral health needs of 12-year-olds in China: Human resources for oral health. BMC Public Health 2017, 17, 1-12. [CrossRef] [PubMed]

27. Zhang, Y.; Lu, Z.; Cheng, R.; Liu, L. Current state of allocation of oral health human resources in northern China and future needs. Int. J. Dent. Hyg. 2015, 13, 268-272. [CrossRef]

28. Ishimaru, M.; Ono, S.; Yasunaga, H.; Matsui, H.; Koike, S. Projected future distribution of dentists in Japan. J. Public Health Dent. 2016, 76, 241-248. [CrossRef] [PubMed]

29. Al-Jarallah, K.F.; Moussa, M.A.A.; Al-Duwairi, Y.; Zaatar, E.; Al-Khanfar, K.F. The dentist workforce in Kuwait to the year 2020. Community Dent. Health 2010, 27, 178-183. [PubMed]

30. Jaiswal, A.K.; Srinivas, P.; Suresh, S. Dental manpower in India: Changing trends since 1920. Int. Dent. J. 2014, 64, 213-218. [CrossRef] 
31. Ahern, S.; Woods, N.; Kalmus, O.; Birch, S.; Listl, S. Needs-based planning for the oral health workforce-Development and ap-plication of a simulation model. Hum. Resour. Health 2019, 17, 1-9. [CrossRef]

32. Ab-Murat, N.; Sheiham, A.; Tsakos, G.; Watt, R. Periodontal treatment needs and workforce requirements: Comparisons between the normative and sociodental approaches using different skill mix models. Community Dent. Oral Epidemiol. 2014, 43, 106-115. [CrossRef] [PubMed]

33. Ab-Murat, N.; Sheiham, A.; Watt, R.; Tsakos, G. Treatment needs and skill mix workforce requirements for prosthodontic care: A comparison of estimates using normative and sociodental approaches. Bmc Oral Health 2015, 15, 1-7. [CrossRef]

34. Gallagher, J.E.; Manickam, S.; Wilson, N.H.F. Sultanate of Oman: Building a dental workforce. Hum. Resour. Health 2015, 13, 50. [CrossRef]

35. Brailsford, S.; De Silva, D. How many dentists does Sri Lanka need? Modelling to inform policy decisions. J. Oper. Res. Soc. 2015, 66, 1566-1577. [CrossRef]

36. Huang, C.S.; Cher, T.-L.; Lin, C.-P.; Wu, K.-M. Projection of the dental workforce from 2011 to 2020, based on the actual workload of 6762 dentists in 2010 in Taiwan. J. Formos. Med. Assoc. 2013, 112, 527-536. [CrossRef]

37. Bourne, C.O. Orthodontic manpower requirements of Trinidad and Tobago. West. Indian Med. J. 2012, 61, 631-634.

38. Gallagher, J.E.; Kleinman, E.R.; Harper, P.R. Modelling workforce skill-mix: How can dental professionals meet the needs and demands of older people in England? Br. Dent. J. 2010, 208, E6. [CrossRef]

39. Gallagher, J.E.; Lim, Z.; Harper, P.R. Workforce skill mix: Modelling the potential for dental therapists in state-funded primary dental care. Int. Dent. J. 2013, 63, 57-64. [CrossRef] [PubMed]

40. Wanyonyi, K.L.; Radford, D.R.; Harper, P.R.; Gallagher, J.E. Alternative scenarios: Harnessing mid-level providers and evidence-based practice in primary dental care in England through operational research. Hum. Resour. Health 2015, 13, 1-12. [CrossRef] [PubMed]

41. Mills, R.W. UK dental care for children-A specialist workforce analysis. Br. Dent. J. 2020, 1-5, 1-5. [CrossRef] [PubMed]

42. Cao, S.; Gentili, M.; Griffin, P.M.; Griffin, S.O.; Harati, P.; Johnson, B.; Serban, N.; Tomar, S. Estimating Demand for and Supply of Pediatric Preventive Dental Care for Children and Identifying Dental Care Shortage Areas, Georgia. Public Health Rep. 2017, 132, 343-349. [CrossRef]

43. Eklund, S.A.; Bailit, H.L. Estimating the Number of Dentists Needed in 2040. J. Dent. Educ. 2017, 81, eS146-eS152. [CrossRef]

44. Saman, D.M.; Arevalo, O.; Johnson, A.O. The dental workforce in Kentucky: Current status and future needs. J. Public Health Dent. 2010, 70, 188-196. [CrossRef]

45. Surdu, S.; Dall, T.M.; Langelier, M.; Forte, G.J.; Chakrabarti, R.; Reynolds, R.L. The pediatric dental workforce in 2016 and beyond. J. Am. Dent. Assoc. 2019, 150, 609-617.e5. [CrossRef]

46. Federation, F.W.D. Oral health workforce planning for developed countries. Int. Dent. J. 2005, 55, 42-44. [CrossRef] [PubMed]

47. Gallagher, J.E.; Hutchinson, L. Analysis of human resources for oral health globally: Inequitable distribution. Int. Dent. J. 2018, 68, 183-189. [CrossRef]

48. Brennan, D.; Balasubramanian, M.; Spencer, A. Treatment of caries in relation to lesion severity: Implications for minimum intervention dentistry. J. Dent. 2015, 43, 58-65. [CrossRef]

49. Brennan, D.; Balasubramanian, M.; Spencer, A. Diagnostic services in Australia: Service rates and characteristics of patients. Aust. Dent. J. 2016, 61, 298-303. [CrossRef]

50. Brennan, D.; Balasubramanian, M.; Spencer, A. Restorative treatment for initial, cavitated and gross coronal carious lesions. Aust. Dent. J. 2016, 61, 350-356. [CrossRef]

51. Brennan, D.S.; Balasubramanian, M.; Spencer, A.J. Trends in dental service provision in Australia: 1983-1984 to 2009-2010. Int. Dent. J. 2015, 65, 39-44. [CrossRef]

52. Hillestad, R.; Bigelow, J.; Bower, A.; Girosi, F.; Meili, R.; Scoville, R.; Taylor, R. Can Electronic Medical Record Systems Transform Health Care? Potential Health Benefits, Savings, And Costs. Health Aff. 2005, 24, 1103-1117. [CrossRef]

53. Baumann, L.A.; Baker, J.; Elshaug, A.G. The impact of electronic health record systems on clinical documentation times: A systematic review. Heal. Policy 2018, 122, 827-836. [CrossRef] [PubMed]

54. Burton, L.C.; Anderson, G.F.; Kues, I.W. Using Electronic Health Records to Help Coordinate Care. Milbank Q. 2004, 82, 457-481. [CrossRef] [PubMed]

55. Schleyer, T.K.; Thyvalikakath, T.P.; Spallek, H.; Dziabiak, M.P.; Johnson, L.A. From information technology to informatics: The in-formation revolution in dental education. J. Dent Educ. 2012, 76, 142-153. [CrossRef]

56. Spallek, H.; Johnson, L.; Kerr, J.; Rankin, D. Costs of health IT: Beginning to understand the financial impact of a dental school EHR. J. Dent. Educ. 2014, 78, 1542-1551. [CrossRef] [PubMed]

57. Johnson, L.; Callaghan, C.; Balasubramanian, M.; Haq, H.; Spallek, H. Cost Comparison of an On-Premise IT Solution with a Cloud-Based Solution for Electronic Health Records in a Dental School Clinic. J. Dent. Educ. 2019, 83, 895-903. [CrossRef]

58. Balasubramanian, M.; IADR. International Association for Dental Research, Network for Practice Based Research. 2020. Available online: https:/ / www.iadr.org/IADR/Join-Renew/Groups-Networks/Network-for-Practice-Based-Research (accessed on 10 January 2020). 
59. Bronkhorst, E.M.; Truin, G.J.; Batchelor, P.; Sheiham, A. Health Through Oral Health; Guidelines for Planning and Monitoring for Oral Health Care. J. Public Health Dent. 1991, 51, 223-227. [CrossRef] [PubMed]

60. Brocklehurst, P.; Tickle, M. Planning a dental workforce for the future for the National Health Service in the United Kingdom: What factors should be accounted for? Health Educ. J. 2011, 71, 340-349. [CrossRef]

61. O’Malley, L.; Macey, R.; Allen, T.; Brocklehurst, P.; Thomson, F.; Rigby, J.; Lalloo, R.; Murphy, G.T.; Birch, S.; Tickle, M. Workforce Planning Models for Oral Health Care: A Scoping Review. JDR Clin. Transl. Res. 2020. [CrossRef] [PubMed] 